\title{
Surface speed and frontal ablation of Kronebreen and Kongsbreen, NW Svalbard, from SAR offset tracking
}

\author{
T. Schellenberger ${ }^{1}$, T. Dunse ${ }^{1}$, A. Kääb ${ }^{1}$, J. Kohler ${ }^{2}$, and C. H. Reijmer ${ }^{3}$ \\ ${ }^{1}$ Department of Geosciences, University of Oslo, P.O. Box 1047, Blindern, 0316 Oslo, Norway \\ ${ }^{2}$ Norwegian Polar Institute, Fram Centre, Troms $\varnothing$, Norway \\ ${ }^{3}$ Institute for Marine and Atmospheric Research Utrecht, Utrecht University, Princetonplein 5, \\ 3584 CC Utrecht, the Netherlands \\ Correspondence to: T. Schellenberger (thomas.schellenberger@geo.uio.no)
}

Received: 18 November 2014 - Published in The Cryosphere Discuss.: 18 December 2014

Revised: 26 November 2015 - Accepted: 27 November 2015 - Published: 15 December 2015

\begin{abstract}
Kronebreen and Kongsbreen are among the fastest-flowing glaciers on Svalbard and, therefore, important contributors to the total dynamic mass loss from the archipelago. Here, we present a time series of area-wide surface velocity fields from April 2012 to December 2013 based on offset tracking on repeat high-resolution Radarsat-2 U1trafine data. Surface speeds reached up to $3.2 \mathrm{~m} \mathrm{~d}^{-1}$ near the calving front of Kronebreen in summer 2013 and $2.7 \mathrm{~m} \mathrm{~d}^{-1}$ at Kongsbreen in late autumn 2012. Additional velocity fields from Radarsat-1, Radarsat- 2 and TerraSAR-X data since December 2007 together with continuous GPS measurements on Kronebreen since September 2008 revealed complex patterns in seasonal and interannual speed evolution. Part of the ice-flow variations seem closely linked to the amount and timing of surface meltwater production and rainfall, both of which are known to have a strong influence on the basal water pressure and hence basal lubrication. In addition, terminus retreat and the associated reduction in back stress appear to have influenced the speed close to the calving front, especially at Kongsbreen in 2012 and 2013. Since 2007, Kongsbreen retreated up to $1800 \mathrm{~m}$, corresponding to a total area loss of $2.5 \mathrm{~km}^{2}$. In 2011 the retreat of Kronebreen of up to $850 \mathrm{~m}$, responsible for a total area loss of $2.8 \mathrm{~km}^{2}$, was triggered after a phase of stable terminus position since $\sim 1990$. Retreat is an important component of the mass balance of both glaciers, in which frontal ablation is the largest component. Total frontal ablation between April 2012 and December 2013 was estimated to $0.21-0.25 \mathrm{Gt} \mathrm{a}^{-1}$ for Kronebreen and $0.14-0.16 \mathrm{Gt} \mathrm{a}^{-1}$ for Kongsbreen.
\end{abstract}

\section{Introduction}

Extended mass loss made glaciers the most important cryospheric contributors to global eustatic sea-level rise in the 20th century, and projections from surface mass balance models estimate additional loss of glaciers outside Antarctica of 0.07 to $0.26 \mathrm{~m}$ sea-level equivalent by 2100 (Church et al., 2013). These estimates do not yet include dynamic glacier wastage, which is poorly constrained but might play an important role over the course of the next centuries (Church et al., 2013).

Glacier velocity $v$ depends amongst others on basal drag (Clarke, 1987), which itself is a function of temperature at the glacier bed and basal water pressure. When temperature at the bed is below the pressure melting point, the glacier is frozen to the ground and only deforms at a rate of a few meters to tens of meters per year. When the glacier bed is temperate, as is the case for the lower parts of Kronebreen and Kongsbreen studied here, fast basal motion may occur, and speed is then mainly constrained by basal water pressure and driving stress.

The total mass balance of tidewater glaciers such as Kronebreen and Kongsbreen comprises two components: the climatic-basal balance $(B)$ and the frontal ablation $A_{\mathrm{f}}(\mathrm{Cog}-$ ley et al., 2011). Three individual processes cause frontal ablation, namely iceberg calving $D$, subaerial frontal melting and sublimation $A_{\mathrm{f}(\mathrm{air})}$, and subaqueous melt $A_{\mathrm{f}(\mathrm{wtr})}$. The importance of frontal melt was first highlighted on LeConte glacier in Alaska by Motyka et al. (2003), where melt was estimated to be $57 \%$ of the total ice loss at the glacier front. 
Subaqueous melt has also been widely studied in Greenland (e.g., Holland et al., 2008) and for the Antarctic ice shelves (e.g., Pritchard et al., 2012), but little information exists on the importance of frontal melt for Svalbard glaciers so far (Vieli et al., 2002). Iceberg calving, the second process, is primarily controlled by stretching of the ice body due to speed gradients and subsequent opening and propagation of crevasses (first-order process, Benn et al., 2007). Secondorder processes include instability of ice cliffs at the calving front, undercutting of the terminus by subaqueous melt as well as buoyancy (Benn et al., 2007). Airborne or spaceborne remote-sensing techniques are not capable of distinguishing between calving and melt but can be used to estimate total frontal ablation by combining ice-flow $q_{\text {fg }}$ through a defined flux gate and mass changes $q_{\mathrm{t}}$ at the terminus.

In this study we investigate the interannual and seasonal variability of surface speeds of Kronebreen and Kongsbreen, two fast-flowing tidewater glaciers in northwestern Svalbard, and demonstrate the importance of $A_{\mathrm{f}}$ for their total mass balance. We present a time series of area-wide speed fields based on synthetic aperture radar (SAR) offset tracking of Radarsat-2 Ultrafine data spanning the period April 2012 to December 2013. The speed maps and cross sections of the calving fronts are then combined with terminus position changes and geometry to calculate the frontal ablation of Kronebreen and the northern branch of Kongsbreen. Additionally, time series and snapshots of velocity fields from Radarsat-1 Wide, Radarsat-2 Wide and TerraSAR-X data between December 2007 and November 2013 give a broader picture on the dynamic behavior of both tidewater glaciers. To assess the accuracy and temporal representativeness of SAR-based speed, we compare it to local glacier speed derived from 16 global GPS stations on Kronebreen. Temperature and precipitation records from an automatic weather station in Ny-Ålesund, are employed to investigate links between potential melt- and rainwater supply to the bed and glacier speed. Terminus positions are digitized from SAR intensity images and, together with the speed maps and auxiliary data, used to estimate frontal ablation.

\section{Study Area}

\subsection{Kronebreen}

Kronebreen is fed by Holtedahlfonna (together $295 \mathrm{~km}^{2}$ ) and Infantfonna $\left(77 \mathrm{~km}^{2}\right)$ and encompasses an elevation range of 0-1400 m a.s.1. (Nuth et al., 2013; Fig. 1). Kronebreen surged in 1868 or 1869 (Liestøl, 1988; Hagen et al., 1993), and until 1995 the glacier had retreated $10-11 \mathrm{~km}$ from its maximum extent in 1868 or 1869 (Melvold and Hagen, 1998; Svendsen et al., 2002). The retreat was interrupted by a surge of the neighboring Kongsvegen in 1948 with a major advance of $4 \mathrm{~km}$ (Melvold and Hagen, 1998). At that time both glaciers shared the same calving front, but Kongsve- gen successively retreated afterwards (Kääb et al., 2005) and is still in its quiescence phase with a speed of $\sim 2 \mathrm{~m} \mathrm{a}^{-1}$ at the terminus (Nuth et al., 2012). Kronebreen, in sharp contrast, is one of the fastest-flowing glaciers in Svalbard (Lefauconnier et al., 1994). Speed estimates of Kronebreen exist from different sources and were summarized by Kääb et al. (2005) (Table 1). A constant mean annual speed of $2.15 \mathrm{~m} \mathrm{~d}^{-1}$ at the front is reported between 1964 and 1979 (Lefauconnier, 1987, in Lefauconnier et al., 1994). Kääb et al. (2005) found an interannual variability of $15 \%$ and measured a mean speed of $1.6 \mathrm{~m} \mathrm{~d}^{-1}$ for the period 1999-2002. Rolstad and Norland (2009) used ground-based radar interferometry to infer speed variations on an hourly timescale and estimated frontal retreat for single calving events. Köhler et al. (2012) used glacier speed close to the calving front from GPS (which is also used in this study) to link the glacier speed to seismicity of calving events. Luckman et al. (2015) combined a time series of velocity maps based on TerraSAR$\mathrm{X}$ data and information on air and sea temperature to link the retreat of Kronebreen to the influence of warm ocean water entering the Kongsfjorden.

The frontal ablation in the mid-1980s was estimated to be $0.25 \mathrm{~km}^{3} \mathrm{a}^{-1}$ (Lefauconnier et al., 1994). A long-term frontal ablation of $0.141 \pm 0.031 \mathrm{Gt} \mathrm{a}^{-1}$ was estimated for the period 1966-1990 by combining geodetic elevation changes and mass balance modeling (Nuth et al., 2012). Frontal ablation increased to $0.198 \pm 0.045 \mathrm{Gt} \mathrm{a}^{-1}$ between 1990 and 2007 , whereas the surface mass balance amounted $0.006 \pm 0.020$ and $-0.069 \pm 0.029 \mathrm{Gt} \mathrm{a}^{-1}$, respectively. Net mass loss was therefore dominated by frontal ablation.

\subsection{Kongsbreen}

Kongsbreen is located north of Kronebreen (Fig. 1) and together with its accumulation area Isachsenfonna, it encompasses an area of $378 \mathrm{~km}^{2}$ and an elevation range of 0-1400 ma.s.1. (Nuth et al., 2013). It splits up into two branches, of which the fast-flowing northern branch ends in a deep fjord ( $\sim 140 \mathrm{~m}$ depth at the 2007 terminus position), and the slow-moving southern branch is partially land terminating. The northern branch, on which we focus in this study, retreated by $>1.5 \mathrm{~km}$ between 1990 and 2007 and experienced extensive dynamic thinning of the terminus area of $-3 \mathrm{~m} \mathrm{a}^{-1}$ in that period, which is partially linked to the retreat (Nuth et al., 2012). Note that this thinning rate refers to fixed positions upstream of the front but not to the retreating front, the height of which above sea remained roughly constant.

\section{Data}

\subsection{Synthetic aperture radar}

Synthetic aperture radar (SAR) allows imaging of the Earth's surface regardless of illumination conditions and cloud cover. 

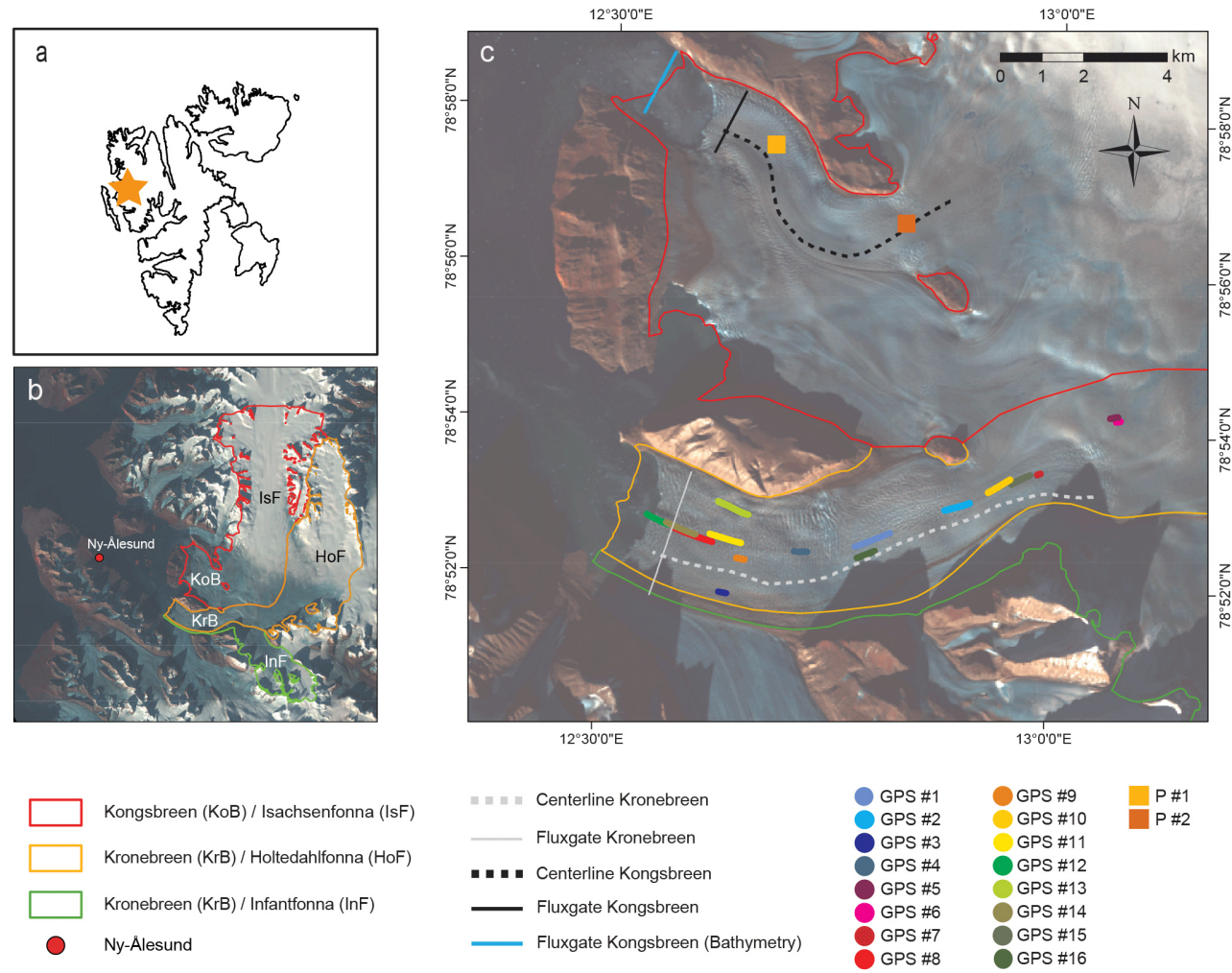

Figure 1. (a) The Svalbard archipelago with location of study area; (b) NW Svalbard from Landsat 8 OLI including Kronebreen (KrB) with its accumulation areas Holtedahlfonna (HoF) and Infantfonna (InF), as well as Kongsbreen (KoB) fed by Isachsenfonna (IsF); and (c) close-up of the area covered by Radarsat-2 Ultrafine images. Positions of 16 GPS stations on Kronebreen between September 2009 and December 2013, the fluxgates used to constrain the cross section of the termini and flow lines used to extract speed profiles. Glacier outlines (2000) taken from Nuth et al. (2013).

Table 1. Studies on speed of Kronebreen (sources: Kääb et al., 2005, Rolstad and Norland, 2009, Köhler et al., 2012, and Luckman et al., 2015).

\begin{tabular}{llr}
\hline Study & Data/method & Years \\
\hline Pillewizer and Voigt (1968) & terrestrial photogrammetry & $1962-1965$ \\
Lefauconnier (1987) & terrestrial photogrammetry & $1983-1986$ \\
Lefauconnier et al. (1994), Rolstad (1995) & SPOT image matching/aerial imagery & 1986 \\
Melvold (1992) & terrestrial photogrammetry stake measurements & 1990 \\
Wangensteen et al. (1999), Eldhuset et al. (2003) & D-InSAR ERS tandem data & 1996 \\
Kääb et al. (2005) & Landsat and ASTER image matching & $1999-2002$ \\
Rolstad and Norland (2009) & ground-based radar/interferometry & 2007 \\
Köhler et al. (2012) & GPS & $2009 / 2010$ \\
Luckman et al. (2015) & TerraSAR-X & $2013 / 2014$ \\
\hline
\end{tabular}

It is therefore well suited for Arctic environments such as Svalbard, where polar night regularly hinders the acquisition of optical data in winter and there is widespread cloud cover during summer. The Radarsat-1 and Radarsat-2 (RS-1, RS-2) satellites have a C-band sensor $(5.3 / 5.405 \mathrm{GHz}$ center frequency) on board and a repetition cycle of 24 days. The RS-1 Wide (RS-1 W) data used in this study were acquired between December 2007 and April 2008. The acquisitions were continued by RS-2 from February 2009 until Novem- ber 2013. Ground resolution of the "Wide mode" data (RS$2 \mathrm{~W}$ ) after multilooking is $\sim 20 \mathrm{~m}$. RS-2 Ultrafine (RS-2 UF) data acquired between 14 April 2012 and 29 December 2013 have a ground resolution of $2 \mathrm{~m}$. Additionally, glacier surface velocity was measured from three scenes acquired in 2008 by TerraSAR-X (TSX), an X-band sensor with a center frequency of $9.65 \mathrm{GHz}$. These data come at a temporal resolution of 11 days, a ground resolution of $2 \mathrm{~m}$ and are dually polarized (VH/VV, HV/HH). A more detailed overview 
Table 2. Synthetic aperture radar data characteristics: satellite, sensor mode, polarization, resolution of intensity images and speed maps as well as step size and search window used for offset tracking.

\begin{tabular}{|c|c|c|c|c|c|c|c|}
\hline Sensor & Mode & Acronym & Polarization & $\begin{array}{r}\text { Repeat pass } \\
\text { (days) }\end{array}$ & $\begin{array}{r}\text { Resolution } \\
\text { int./speed }(\mathrm{m})\end{array}$ & $\begin{array}{r}\text { Step size } \\
\text { (pixels) }\end{array}$ & $\begin{array}{r}\text { Search window } \\
\text { (pixels) }\end{array}$ \\
\hline Radarsat-1 & Wide & RS-1 W & $\mathrm{HH}$ & 24 & $20 / 100$ & $5 \times 20$ & $40 \times 160$ \\
\hline \multirow[t]{4}{*}{ Radarsat-2 } & Wide & RS-2 W & $\mathrm{HH}$ & 24 & $20 / 100$ & $5 \times 20$ & $40 \times 160$ \\
\hline & & & $\mathrm{HH}$ & $\geq 48$ & $20 / 200$ & $10 \times 40$ & $80 \times 320$ \\
\hline & Ultrafine & RS-2 UF & $\mathrm{HH}$ & 24 & $2 / 50$ & $27 \times 26$ & $135 \times 130$ \\
\hline & & & $\mathrm{HH}$ & $\geq 48$ & $2 / 50$ & $27 \times 26$ & $536 \times 488$ \\
\hline TerraSAR-X & HRSL & TSX & $\begin{array}{l}\text { VH/VV, } \\
\mathrm{HV} / \mathrm{HH}\end{array}$ & 11 & $2 / 50$ & $24 \times 23$ & $96 \times 92$ \\
\hline
\end{tabular}

of the data characteristics (mode, polarization, resolution, repeat-pass interval) and processing parameters (step size and search window for offset tracking) is given in Table 2.

\subsection{Continuous GPS observations}

Between 2009 and 2013, 12 GPS receivers were deployed at various locations of Kronebreen to monitor its flow. We used single-frequency GPS receivers designed to operate unattended for a period of 1-3 years (den Ouden et al., 2010). Positions are acquired every $3 \mathrm{~h}$ and transmitted via the ARGOS satellite system, and the nominal accuracy of each position is estimated to be $1.6 \mathrm{~m}$ (den Ouden et al., 2010).

\subsection{Ice thickness}

\subsubsection{Kronebreen}

Ice thickness data of Kronebreen were obtained in 2009 and 2010 using a pulsed $10 \mathrm{MHz}$ radar system suspended beneath a helicopter (J. Kohler, personal communication, 2014). The vertical precision was conservatively estimated to be ca. $\pm 20 \mathrm{~m}$, based on crossover analysis of the derived ice depths. This uncertainty should also include potential seasonal and interannual variations in ice thickness. Accuracy was more difficult to estimate; the only borehole drilled to the bed (D. Benn, personal communication, 2014) found ice thickness to be $305 \mathrm{~m}$ at a location where the bed map predicted $310 \mathrm{~m}$.

\subsubsection{Kongsbreen}

Ice thickness $H$ of Kongsbreen was not directly measured but constrained by the height of the ice cliff above sea-level $z_{\mathrm{s}}$ and water depth from bathymetric surveying in 2007 as approximation for the ice thickness of the subaqueous part of the calving front $z_{\mathrm{b}}$, with

$H=z_{\mathrm{s}}+z_{\mathrm{b}}$,

where $z_{\mathrm{s}}$ was estimated to vary within a range of $40 \pm 15 \mathrm{~m}$ based on a SPOT-5 SPIRIT DEM derived from data ac- quired in September 2007 (Korona et al., 2009). The SPOT DEM has a RMSE of $6.8 \mathrm{~m}$ compared to ICESat data. A water depth profile, $z_{\mathrm{b}}$, was extracted from the bathymetric data along a gate close to the terminus position of 2007 (Fig. 1c and e) and used as a cross section of the submerged part of the terminus. The horizontal and vertical accuracy of the bathymetry is better than 1 and $0.1 \mathrm{~m}$, respectively (B. Kuipers, personal communication, 2014). Nevertheless, higher uncertainties arise in the calculation of the frontal ablation from the retreat of Kongsbreen, as there is no information on bedrock topography and, hence, ice thickness at the exact position of the fluxgate where the actual speed is retrieved. Based on the variations in water depth within $1.5 \mathrm{~km}$ from the front of the 2007 terminus ( $3 \sigma$ corresponding to $\pm 15 \mathrm{~m}$ ), we assumed a conservative uncertainty of $\pm 15 \mathrm{~m}$. Both vertical uncertainties of $\pm 15 \mathrm{~m}$ each, the one from surface elevation and the one from bed elevation together making up ice thickness, should also include potential seasonal and interannual variations in ice thickness

\subsection{Meteorological data}

Surface meltwater and rain are potential drivers of subglacial hydrology and hence ice flow. To estimate the timing and magnitude of both factors, we considered temperature and precipitation records from a meteorological station in $\mathrm{Ny}$ Ålesund $\left(78.92^{\circ} \mathrm{N}, 11.93^{\circ} \mathrm{E} ; 8 \mathrm{~m}\right.$ a.s.l.), some $15 \mathrm{~km}$ away from Kronebreen. From the temperature record, we extracted positive degree days (PDD) as a measure of daily surface meltwater production and calculated cumulative positive degree days (CPDD) as cumulative production over the melt season (Ohmura, 2001). The station record contains information on the amount and the type of precipitation (snow, rain +29 other classes). As we are solely interested in liquid precipitation, we classified precipitation as "rain" when daily mean temperature was above $0^{\circ} \mathrm{C}$. 


\section{Method}

\subsection{SAR offset tracking}

SAR offset tracking is a well-established technique, in which for a pair of consecutive SAR acquisitions, displacements are determined using cross-correlation of the intensity images (Strozzi et al., 2002). In our study, the size of the correlation matching window was adjusted according to the image resolution and expected maximum displacements during the repeat pass cycle (Table 2). Velocities were calculated from displacements by accounting for the time interval $\Delta t$ between the two underlying images and geocoded using the SPOT SPIRIT DEM. Speeds larger than the measured maximum speed at the calving front were classified as mismatches and removed. To extract speed profiles and estimate the ice flux, remaining erroneous speed estimates (local abnormal values in magnitude, identified by visual inspection) were removed, and the maps were interpolated using inverse distance weighting to provide continuous speed profiles. Examples of filtered and interpolated speed maps of Kronebreen and Kongsbreen from SAR feature tracking using RS-2 UF, RS-2 W and TSX data are shown in Fig. 2.

A quantitative validation of the speed maps was carried out by comparing SAR-based displacements $d$ against displacements of GPS stations $d_{\mathrm{GPS}}$ on Kronebreen and against stable ground. The first test between RS-2 UF displacements $d_{\mathrm{RS}-2 \mathrm{UF}}$ and GPS displacements $d_{\mathrm{GPS}}$ for all repeat-pass periods showed very good agreement $\left(R^{2}=\right.$ $\left.0.99, \mathrm{RMSE}=0.11 \mathrm{~m} \mathrm{~d}^{-1}, d_{\mathrm{RS}-2 \mathrm{UF}}=0.92 d_{\mathrm{GPS}}+0.10\right)$, although SAR underestimated local speed at the GPS stations by $7.6 \%$ (Fig. 3). Displacements derived from RS-2 W data $d_{\mathrm{RS}-2 \mathrm{~W}}$ are less accurate $\left(R^{2}=0.90, \mathrm{RMSE}=0.17 \mathrm{~m} \mathrm{~d}^{-1}\right.$, $\left.d_{\mathrm{RS}-2 \mathrm{~W}}=0.87 d_{\mathrm{GPS}}+1.80\right)$, but the tendency to underestimate is only observed for large displacements.

The apparent displacement of stable bedrock points is an accuracy measure for the co-registration process. We estimated the accuracy of each displacement map based on the mean displacements $( \pm 1 \sigma)$ of 24 manually selected stable points to $0.9 \pm 1.0 \mathrm{~m}$ for RS-2 UF, $3.3 \pm 2.6 \mathrm{~m}$ for RS- $1 \mathrm{~W}$, $1.9 \pm 1.6 \mathrm{~m}$ for RS- $2 \mathrm{~W}$ and $1.0 \pm 0.6 \mathrm{~m}$ for TSX (Fig. 4).

\subsection{Frontal ablation}

The calculation of $A_{\mathrm{f}}$ of Kronebreen and Kongsbreen closely follows the approach described in Dunse et al. (2015), which sums up the ice flux $q_{\mathrm{fg}}$ through a fixed fluxgate above the position of the calving front, which is variable in time, and the mass change in the terminus below the fluxgate $q_{\mathrm{t}}$ due to advance or retreat:

$A_{\mathrm{f}}=q_{\mathrm{fg}}+q_{\mathrm{t}}$.

The spatially fixed fluxgate is defined approximately perpendicular to the ice flow, 250-1300 m upglacier from the actual calving front (Fig. 1), where ice surface speed $v_{\mathrm{fg}}$ could be

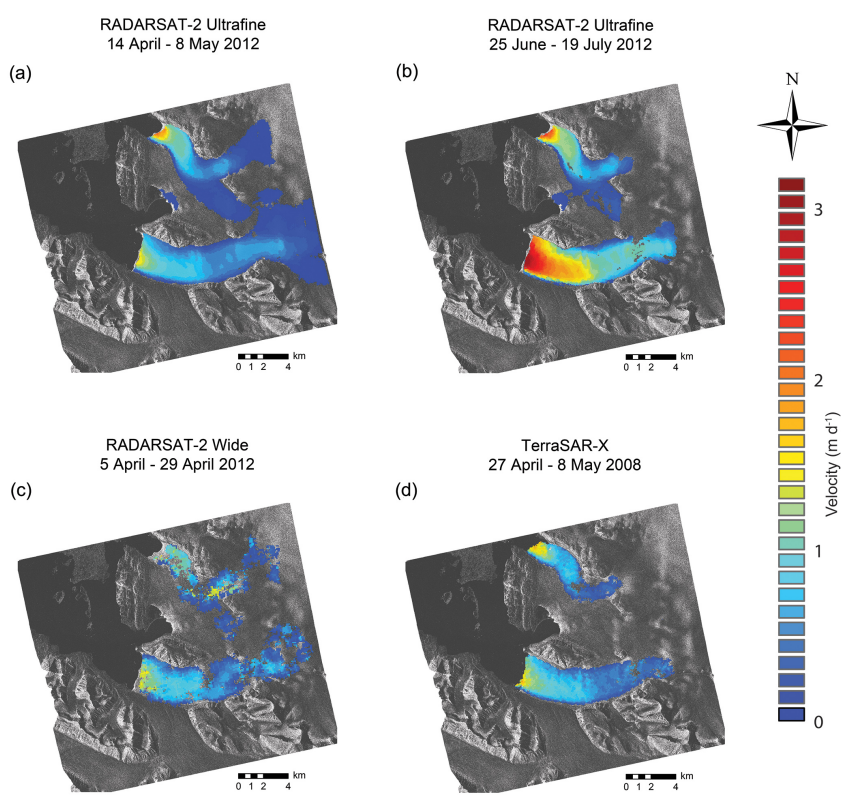

Figure 2. Selected speed fields of Kronebreen and Kongsbreen from SAR feature tracking: (a) RS-2 UF 14 April 2012-8 May 2012, (b) RS-2 UF 25 June 2012-19 July 2012, (c) RS-2 W 5 April 201229 April 2012, and (d) TSX 27 April 2008-8 May 2008.

extracted from all RS-2-UF-based speed maps. $q_{\mathrm{fg}}$ can be written as

$q_{\mathrm{fg}}=v_{\mathrm{da}} \times H_{\mathrm{fg}} \times w_{\mathrm{fg}}$,

where $H_{\mathrm{fg}}$ is the ice thickness along the fluxgate and $w_{\mathrm{fg}}$ is the width of the fluxgate. The depth-averaged speed $v_{\mathrm{da}}$ along the fluxgate is $v_{\text {fg }}$ along the fluxgate weighted by a correction factor $f_{\text {da }}$ between 0.8 and 1.0 accounting for a likely range of basal drag (Cuffey and Paterson, 2010):

$v_{\mathrm{da}}=f_{\mathrm{da}} \times v_{\mathrm{fg}}$.

\subsubsection{Terminus position changes}

Frontal ablation associated with position changes in the calving front between two subsequent SAR acquisitions are calculated by multiplying the observed changes in glacier area downstream from the fixed fluxgate with an average ice thickness of the terminus $H_{\mathrm{t}}$

$q_{\mathrm{t}}=H_{\mathrm{t}} \times \frac{\Delta A_{\mathrm{t}}}{\Delta t}$,

where $H_{\mathrm{t}}$ is the ice thickness at the terminus in the vicinity of the calving front. $\Delta A_{\mathrm{t}}$ is the area change in the terminus over the repeat-pass period $\Delta t$ between successive SAR acquisitions. We consider the calving front as relatively stable, when position changes are within a few tens of meters. 

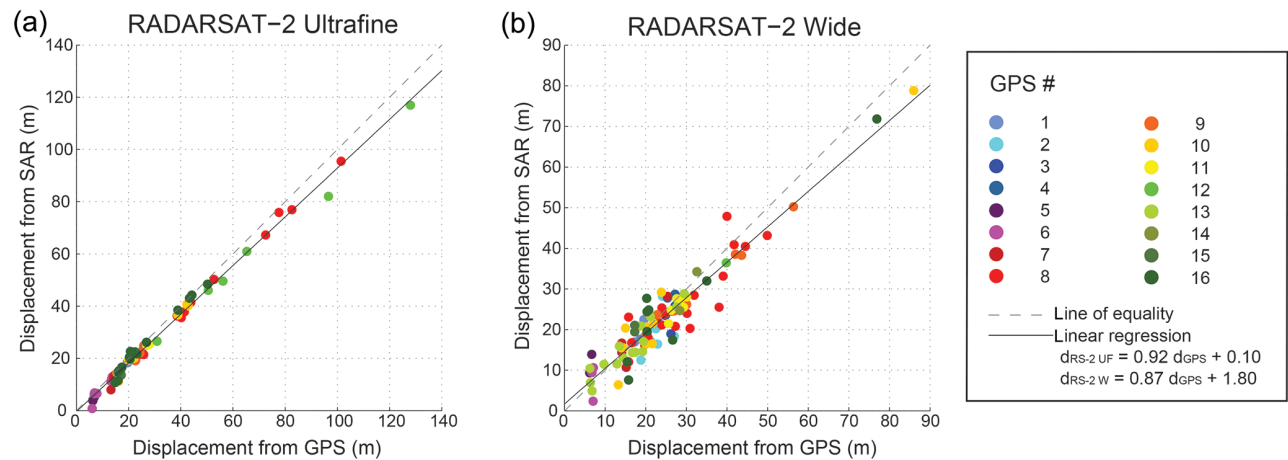

Figure 3. Validation of glacier displacement: displacements extracted from SAR maps at the position of GPS and plotted against GPS displacements: (a) RS-2 UF vs. GPS and (b) RS-2 W vs. GPS.
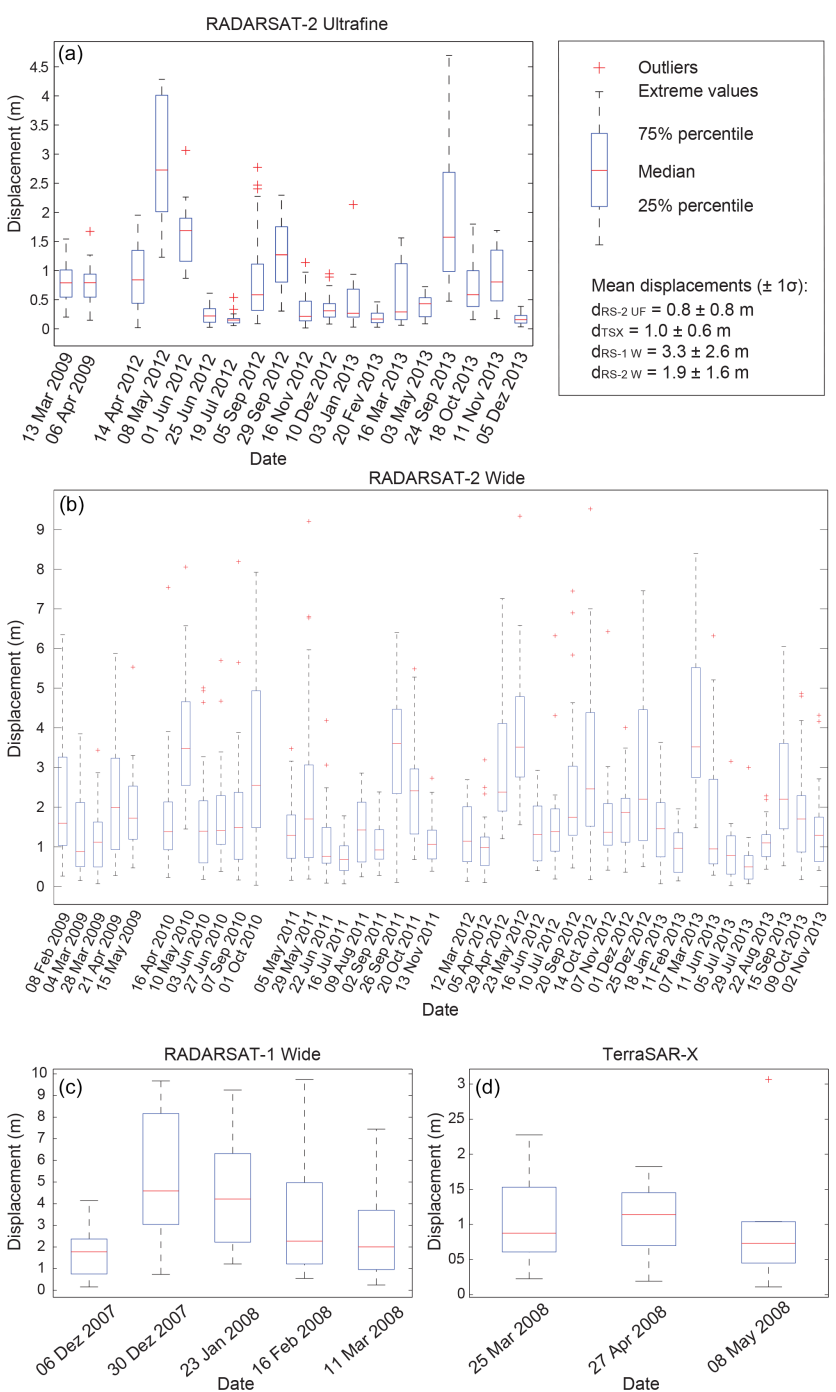

Figure 4. SAR displacement map accuracy assessment. Boxplots of displacements of 16 points on stable ground for each displacement map: (a) RS-2 UF, (b) RS-2 W (c) RS-1 W, and (d) TSX.

\subsubsection{Depth-averaged speed and uncertainties}

In this study, estimates of the frontal ablation (Eq. 1) are always given as range $A_{\mathrm{f} 0.8}-A_{\mathrm{f} 1.0}$, with the lower estimate $A_{\mathrm{f} 0.8}$ based on a correction factor for the depth-averaged speed of $f_{\mathrm{da}}=0.8$ in the calculation of the ice flux (Eq. 3),

$A_{\mathrm{f} 0.8}=q_{\mathrm{fg} 0.8}+q_{\mathrm{t}}=0.8 \times v_{\mathrm{fg}} \times H_{\mathrm{fg}} \times w_{\mathrm{fg}}+H_{\mathrm{t}} \times \frac{\Delta A_{\mathrm{t}}}{\Delta t}$,

and $A_{\mathrm{f} 1.0}$ with $f_{\mathrm{da}}=1.0$,

$A_{\mathrm{f} 1.0}=q_{\mathrm{fg} 1.0}+q_{\mathrm{t}}=1.0 \times v_{\mathrm{fg}} \times H_{\mathrm{fg}} \times w_{\mathrm{fg}}+H_{\mathrm{t}} \times \frac{\Delta A_{\mathrm{t}}}{\Delta t}$.

Mass loss at the terminus $q_{\mathrm{t}}$ is independent of $f_{\mathrm{da}}$ (Eq. 4).

Additionally, we provide in brackets an upper and lower boundary of the frontal ablation, $A_{\mathrm{fmin}}$ and $A_{\mathrm{f} \max }$ based on the uncertainties $(\sigma)$ of the input variables (Tables 3 and 4 ). $A_{\mathrm{f} \text { min }}$ is calculated as

$A_{\mathrm{f} \min }=q_{\mathrm{fg} \min }+q_{\mathrm{t} \min }$.

The lower boundary of the ice flux $q_{\mathrm{fg} \text { min }}$ is estimated by substituting Eq. (3) into Eq. (2),

$q_{\mathrm{fg} \min }=f_{\text {da min }} \times v_{\mathrm{fg} \min } \times H_{\mathrm{fg} \min }$,

with $f_{\text {da min }}=0.8, v_{\text {fg min }}=v_{\text {fg }}-\sigma_{v_{\mathrm{fg}}}$ and $H_{\text {fg min }}=H_{\text {fg }}-$ $\sigma_{H_{\mathrm{fg}}}$.

The minimum mass change through terminus position changes $q_{\mathrm{t} \text { min }}$ is calculated based on Eq. (4), depending on whether the glacier advanced or retreated between time $t$ and $t+1$. In case the glacier advanced $\left(\Delta A_{\mathrm{t}}>0\right)$, the mass gain was minimal, when the height of the calving front $H_{\mathrm{t}}$ was $\operatorname{minimal}\left(H_{\mathrm{t} \min }=H_{\mathrm{t}}-\sigma_{H_{\mathrm{t}}}\right)$ :

$q_{\mathrm{t} \min }=H_{\mathrm{t} \min } \times \frac{\Delta A_{\mathrm{tmin}}}{\Delta t}$.

In the other case, when the glacier advances $\left(\Delta A_{\mathrm{t}}<0\right)$, the mass loss is maximal, when the height of the calving front $H_{\mathrm{t}}$ is maximal $\left(H_{\mathrm{t} \max }=H_{\mathrm{t}}+\sigma_{H_{\mathrm{t}}}\right)$ :

$q_{\mathrm{t} \min }=H_{\mathrm{t} \max } \times \frac{\Delta A_{\mathrm{tmin}}}{\Delta t}$. 
Table 3. Frontal ablation of Kronebreen: input variables - values, sources and uncertainties.

\begin{tabular}{|c|c|c|}
\hline Variable & Uncertainty & Explanation, value and source \\
\hline$H_{\text {fg }}$ & $\sigma_{H_{\mathrm{fg}}}= \pm 20 \mathrm{~m}$ & $\begin{array}{l}\text { Local ice thickness along fluxgate } \\
\text { Ice thickness across fluxgate based on helicopter radar; uncertainty } \\
\text { from cross-track comparison }\end{array}$ \\
\hline$H_{\mathrm{t}}$ & $\sigma_{H_{\mathrm{t}}}= \pm 20 \mathrm{~m}$ & $\begin{array}{l}\text { Mean ice thickness in area of terminus position changes } \\
H_{\mathrm{t}}=122 \mathrm{~m} \\
\text { Ice thickness based on helicopter radar in area of terminus position } \\
\text { changes during observation period; uncertainty from cross-track } \\
\text { comparison }\end{array}$ \\
\hline$v_{\text {fg }}$ & $\sigma_{v_{\mathrm{fg}}}= \pm 0.11 \mathrm{md}^{-1}$ & $\begin{array}{l}\text { Speed value at fluxgate increment from RS-2 UF speed maps } \\
\sigma_{v_{\mathrm{fg}}} \text { is the RMSE of comparison between RS-2 UF and GPS } \\
\text { displacements. }\end{array}$ \\
\hline$\Delta A$ & $\sigma_{\mathrm{t}}= \pm 8.0 \mathrm{~m}$ & $\begin{array}{l}\text { Areal change of terminus derived from calving front position changes } \\
\text { from repeat RS-2 UF intensity images. } \\
\text { Estimated uncertainty } \sigma_{\mathrm{t}} \text { due to imaging geometry and digitizing error } \\
\text { of terminus position results in uncertainty of } \Delta A . \sigma_{\Delta A} \text { is determined } \\
\text { by RSS of deviation from minimum and maximum extent of } A \text { at times } \\
t \text { and } t+1 \text { (Eq. 12). }\end{array}$ \\
\hline
\end{tabular}

In both cases, the minimal change in areal extent is calculated to

$\Delta A_{\mathrm{t} \min }=A_{\mathrm{t}}-A_{\mathrm{t}+1}-\sigma_{A_{\mathrm{f}}}$

As $A_{t}$ and $A_{t+1}$ are independent, their uncertainties are propagated by the root of the sum of squares (RSS) of the uncertainty each component as

$\sigma_{A_{\mathrm{t}}}=\sqrt{\sigma_{A_{\mathrm{t}}}^{2}+\sigma_{A_{\mathrm{t}+1}}^{2}}$.

Similarly, the maximal frontal ablation $A_{\mathrm{f} \max }$ is calculated as

$A_{\text {f max }}=q_{\text {fg } \max }+q_{\text {t max }}$,

where, based on Eqs. (2) and (3), the maximum ice flux $q_{\text {fg max }}$ amounts to

$q_{\text {fg max }}=f_{\text {da max }} \times v_{\text {fg max }} \times H_{\text {fg max }}$,

with

$f_{\text {da } \max }=1.0, v_{\text {fg } \max }=v_{\text {fg }}+\sigma_{v_{\mathrm{fg}}}$ and

$H_{\text {fg max }}=H_{\text {fg }}+\sigma_{H_{\mathrm{fg}}}$.

The maximal mass change through terminus position changes $q_{\mathrm{t} \text { max }}$ is calculated based on Eq. (4), depending on whether the glacier advanced or retreated between time $t$ and $t+1$ as

$q_{\mathrm{t} \max }=H_{\mathrm{t} \max } \times \frac{\Delta A_{\mathrm{t} \max }}{\Delta t}$, when $\Delta A_{\mathrm{t}}>0$, or

$q_{\mathrm{t} \max }=H_{\mathrm{t} \min } \times \frac{\Delta A_{\mathrm{t} \max }}{\Delta t}$, when $\Delta A_{\mathrm{t}}<0$,

with the maximum change in areal extent

$\Delta A_{\mathrm{t} \max }=A_{\mathrm{t}}-A_{\mathrm{t}+1}+\sigma_{A_{\mathrm{f}}}$.

\section{Results}

In the following two sections, we report on recent variations in flow speed, terminus position and frontal ablation of Kronebreen (Sect. 5.1) and Kongsbreen (Sect. 5.2).

\subsection{Kronebreen}

\subsubsection{Glacier surface speed}

In 3 out of 4 years during the observation period, Kronebreen had a distinct seasonal cycle with minimum speed in autumn and winter (here called background speed), a speedup in spring and a well-pronounced summer peak (Fig. 5). Interannual variability was high; for example summer maxima varied from $2.1 \mathrm{~m} \mathrm{~d}^{-1}$ in June and July 2011 to $3.2 \mathrm{~m} \mathrm{~d}^{-1}$ in July and August 2013.

Winter background speeds and summer speedup in 2010 had a medium amplitude compared to the following years (Figs. 5 and 6), coinciding with the lowest meltwater production during the observation period $\left(\mathrm{CPDD}_{2010}=451^{\circ} \mathrm{Cd}\right)$. In 2011 instead, maximum summer speed was lower than during the previous year, despite higher CPDD of $600{ }^{\circ} \mathrm{Cd}$. An abrupt speedup occurred after the ice flow had returned to its slowest speed during the observation period in autumn/winter 2011. This event was triggered by a remarkable rainfall of $98.0 \mathrm{~mm}$, almost one-fourth of the longterm (1981-2010) annual mean precipitation in Ny-Ålesund of $427 \mathrm{~mm} \mathrm{a}^{-1}$ on 30 January 2012 (Førland et al., 2011). Afterwards, the speed continued to increase linearly until the summer speedup 2012 coinciding with strong melt $\left(\mathrm{CPDD}_{2012}=545^{\circ} \mathrm{Cd}\right)$. After surface melt had ceased, the 
Table 4. Frontal ablation of Kongsbreen: input variables - values, sources and uncertainties.

\begin{tabular}{|c|c|c|}
\hline Variable & Uncertainty & Explanation, value and source \\
\hline $\mathrm{Zs}_{\mathrm{fg}}$ & $\sigma_{\mathrm{zs}_{\mathrm{fg}}}= \pm 15 \mathrm{~m}$ & $\begin{array}{l}\text { Local surface elevation in vicinity of the calving front } \\
\mathrm{zs}_{\mathrm{fg}}=40 \mathrm{~m} \\
\text { Height estimation based on SPOT Spirit DEM of } 2007 . \sigma_{\mathrm{zs}_{\mathrm{fg}}} \text { is the RMSE } \\
\text { compared to ICESat data }(6.8 \mathrm{~m}) \text { (Korona et al., 2009) }+ \text { melt. }\end{array}$ \\
\hline $\mathrm{zb}_{\mathrm{fg}}$ & $\sigma_{\mathrm{zb}}= \pm 15 \mathrm{~m}$ & $\begin{array}{l}\text { Local bedrock depth along gate } \mathrm{G}_{2} \\
\text { Water depth extracted from bathymetry along fluxgate close to the calving front } \\
\text { of } 2007 . \sigma_{\mathrm{zb}} \text { is the variation }(3 \sigma) \text { of water depth in deglaciated area of fjord } \\
\text { close to the calving front. }\end{array}$ \\
\hline$H_{\text {fg }}$ & $\sigma_{H_{\mathrm{fg}}}= \pm$ & $\begin{array}{l}\text { Local ice thickness along fluxgate } \\
H_{\mathrm{fg}}=\mathrm{zs}_{\mathrm{fg}}-\mathrm{zb} \text { fg } \\
\text { Combination of height estimate and water depth; uncertainty }=\text { RSS of errors } \\
\text { in } \mathrm{zs}_{\mathrm{fg}} \text { and } \mathrm{zb} \mathrm{b}_{\mathrm{fg}} \text {. }\end{array}$ \\
\hline $\mathrm{zSt}$ & $\sigma_{\mathrm{zs}_{\mathrm{t}}}= \pm 15 \mathrm{~m}$ & $\begin{array}{l}\text { Mean elevation along fluxgate } \\
z_{\mathrm{st}}=40 \mathrm{~m} \\
\text { Height estimation based on SPOT Spirit DEM of } 2007 \text { (Korona et al., 2009). } \\
\sigma_{\mathrm{zs}_{\mathrm{t}}} \text { is estimated from RMSE of SPOT SPIRIT DEM compared to ICESat data } \\
(6.8 \mathrm{~m})+\text { melt. }\end{array}$ \\
\hline $\mathrm{zb}_{\mathrm{t}}$ & $\sigma_{\mathrm{zb}_{\mathrm{t}}}= \pm 15 \mathrm{~m}$ & $\begin{array}{l}\text { Local bedrock depth along fluxgate } \\
\text { Mean water depth along fluxgate close to the calving front of } 2007 \text { (Fig. 1). } \\
\sigma_{\mathrm{zb}_{\mathrm{t}}} \text { is the variation }(3 \sigma) \text { of water depth in deglaciated area of fjord close to the } \\
\text { calving front. }\end{array}$ \\
\hline$H_{\mathrm{t}}$ & $\sigma_{H_{\mathrm{t}}}$ & $\begin{array}{l}\text { Total height of the calving front } \\
H_{\mathrm{t}}=z_{\mathrm{st}}-z_{\mathrm{bt}} \\
\sigma_{H_{\mathrm{t}}} \text { is the RSS of errors in } \mathrm{zs}_{\mathrm{t}} \text { and } \mathrm{zb}_{\mathrm{t}} \text {. }\end{array}$ \\
\hline$v_{\mathrm{fg}}$ & $\sigma_{v_{\mathrm{fg}}}= \pm 0.11 \mathrm{~m} \mathrm{~d}^{-1}$ & $\begin{array}{l}\text { Speed value at fluxgate increment from RS-2 UF speed maps. } \sigma_{v_{\mathrm{fg}}} \text { is the RMSE } \\
\text { of comparison between RS-2 UF and GPS displacements. }\end{array}$ \\
\hline$\Delta A$ & $\sigma_{\mathrm{t}}= \pm 8.0 \mathrm{~m}$ & $\begin{array}{l}\text { Areal change in terminus derived from calving front position changes from } \\
\text { repeat RS-2 UF intensity images. } \\
\text { Estimated uncertainty } \sigma_{\mathrm{t}} \text { due to imaging geometry and digitizing error of } \\
\text { terminus position results in uncertainty of } \Delta A . \sigma_{\Delta A} \text { is determined by RSS of } \\
\text { deviation from minimum and maximum extent of } A \text { at times } t \text { and } t+1 \text { (Eq. 12). }\end{array}$ \\
\hline
\end{tabular}

speed remained high. Measured background speed during winter 2012/2013 was the highest in the period 2010 to 2013.

The most extensive summer speedup was observed in 2013, when ice-flow speed peaked at $3.2 \mathrm{~m} \mathrm{~d}^{-1}$ near the terminus $\left(\mathrm{CPDD}_{2013}=544^{\circ} \mathrm{C} \mathrm{d}\right)$. Accelerated flow reached far inland, with speeds greater than $1 \mathrm{~m} \mathrm{~d}^{-1}$ measured up to $6 \mathrm{~km}$ inland from the calving front at an elevation of $213 \mathrm{~m}$ (Fig. 5b). After a secondary peak coinciding with an intense rain event, the speed decreased to a low background speed in autumn 2013.

\subsubsection{Terminus position changes}

During the entire observation period December 2007 to December 2013, Kronebreen retreated by $\sim 1.1 \mathrm{~km}$, resulting in an area loss of $2.8 \mathrm{~km}^{2}$ (Fig. 7). Between 2007 and 2009 the calving front of Kronebreen was relatively stable. However, we observed seasonal variations in front position of 100$300 \mathrm{~m}$, characterized by advance in spring, retreat in autumn and minor fluctuations of a few tens of meters in both summer and winter. Between May 2011 and December 2011 the terminus retreated up to $400 \mathrm{~m}$, only stabilized to a pinning point in the middle of the caving front, from which it then retreated until March 2012. In 2012, for once, the front did not advance during the summer speedup and between June 2012 and July 2012 the area which was pinned before, retreated behind the rest of the calving front. Afterwards the retreat continued along the whole terminus until 10 December 2012. Kronebreen advanced again until 3 May 2013 and retreated from July until December 2013. 

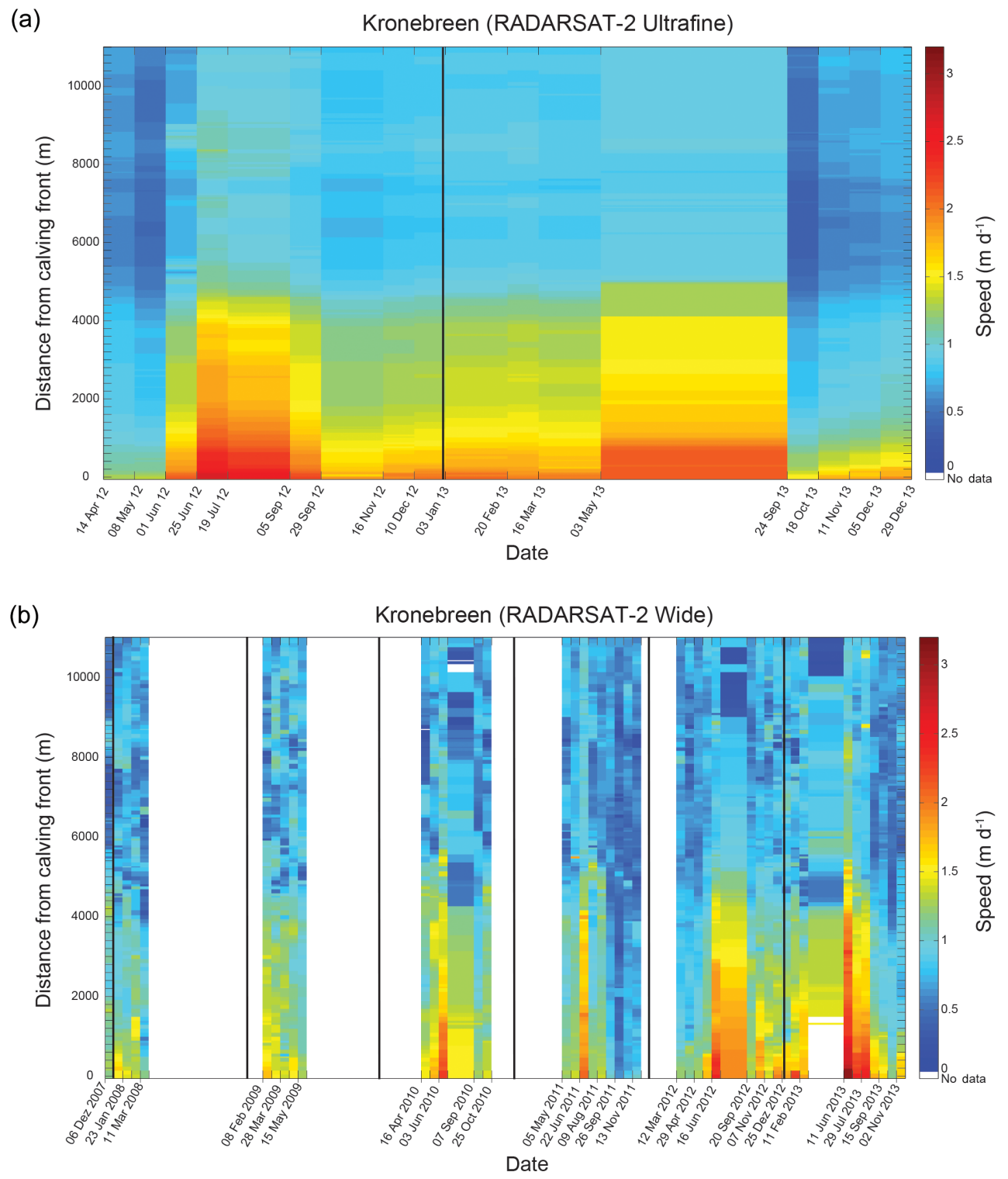

Figure 5. Time series of glacier speed along centerline (see Fig. 1) of Kronebreen between (a) 14 April 2012 and 29 December 2013 based on RS-2 UF data and (b) 6 December 2007 and 26 November 2013 based on RS-1 W data (2007-2008) and RS-2 W data (2009-2013), respectively.

\subsubsection{Frontal ablation}

The quality of the speed maps based on RS-2 UF was good enough to extract speed profiles along the fluxgate close to the calving front, except for the map based on the image pair 3 May 2013-24 September 2013, due to the long gap between the acquisitions. The strong surface changes over such a long period led to complete failure of cross-correlation within the offset tracking as indicated by too low signal-tonoise ratios for the offsets obtained. Consequently we calculated the frontal ablation $A_{\mathrm{f}}$ for each repetition cycle in the period 14 April 2012 to 29 December 2013 by excluding the flux between May and September 2013 (Fig. 8). Mean frontal ablation rates of Kronebreen during that period amounted to $q=0.21-0.25 \mathrm{Gt} \mathrm{a}^{-1}\left(0.16-0.31 \mathrm{Gt} \mathrm{a}^{-1}\right)$ (first range refers to different depth-averaged speed, second range to the complete error budget; see Sect. 4.2.2), whereof $0.06 \mathrm{Gt} \mathrm{a}^{-1}$ was lost through terminus retreat $\left(q_{\mathrm{t}}\right)$ and $0.19 \mathrm{Gt} \mathrm{a}^{-1}$ through ice flux $\left(q_{\mathrm{fg}}\right)$.

We also provide ablation rates for the period 8 May 2012 3 May 2013, a temporal subset of the above full period. This period spans an entire year and is therefore unbiased towards fast flow in summer or slow speed in winter when comparing the data to other studies. Between May 2012 and May 2013 frontal ablation was $q=0.22-0.27 \mathrm{Gt} \mathrm{a}^{-1}$ 

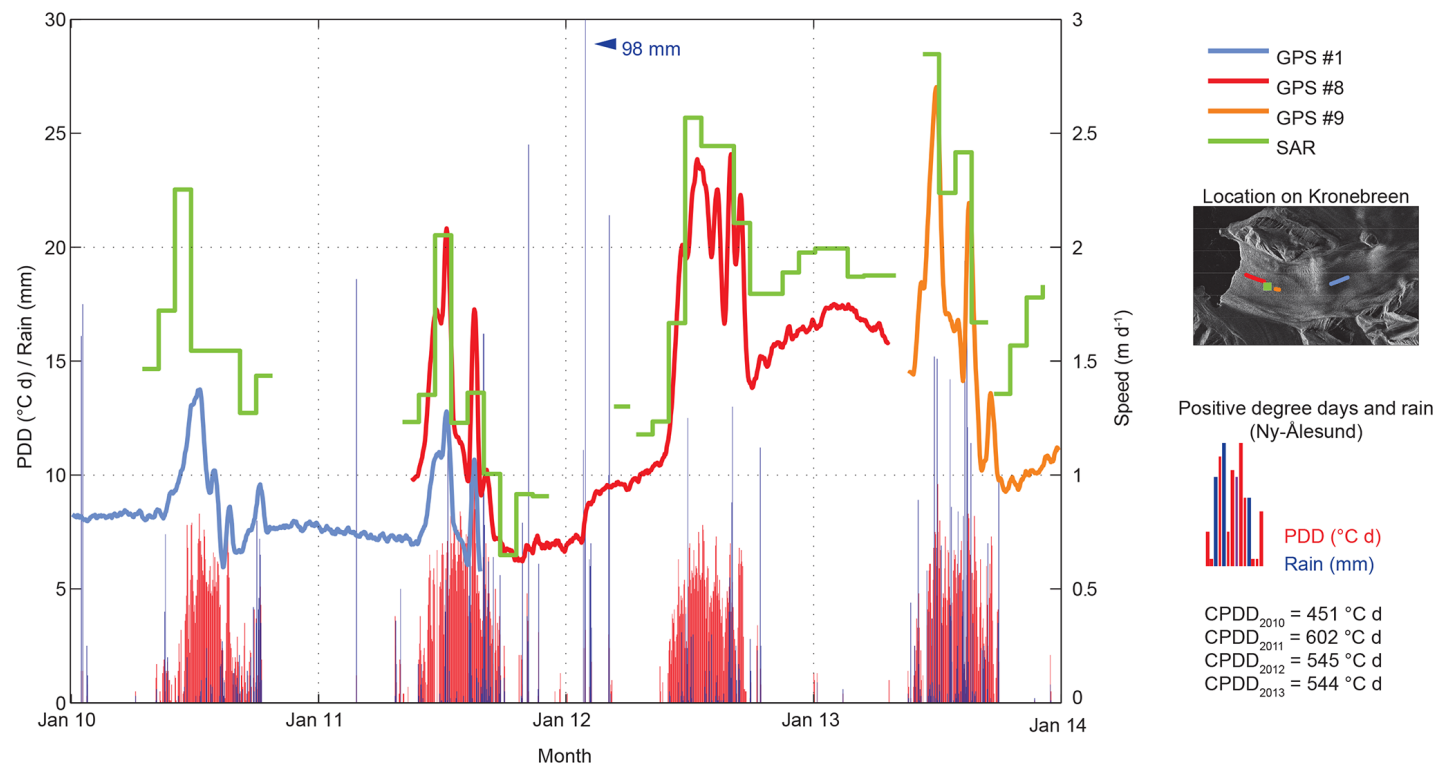

Positive degree days and rain

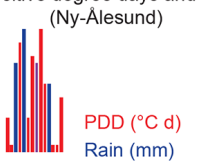

$\mathrm{CPDD}_{2010}=451^{\circ} \mathrm{C} \mathrm{d}$

$\mathrm{CPDD}_{2011}=602^{\circ} \mathrm{C} \mathrm{d}$

$\mathrm{CPDD}_{2013}=544^{\circ} \mathrm{C} \mathrm{d}$

Figure 6. Time series of speed of Kronebreen between 2010 and 2013 linked to water supply by melt (positive degree days $\left({ }^{\circ} \mathrm{C}\right.$ ) and rain events (mm) from weather station in Ny-Ålesund). Speed of Kronebreen ( $\mathrm{m} \mathrm{d}^{-1}$ ) derived from RS-2 (green) and GPS (blue/red/orange).
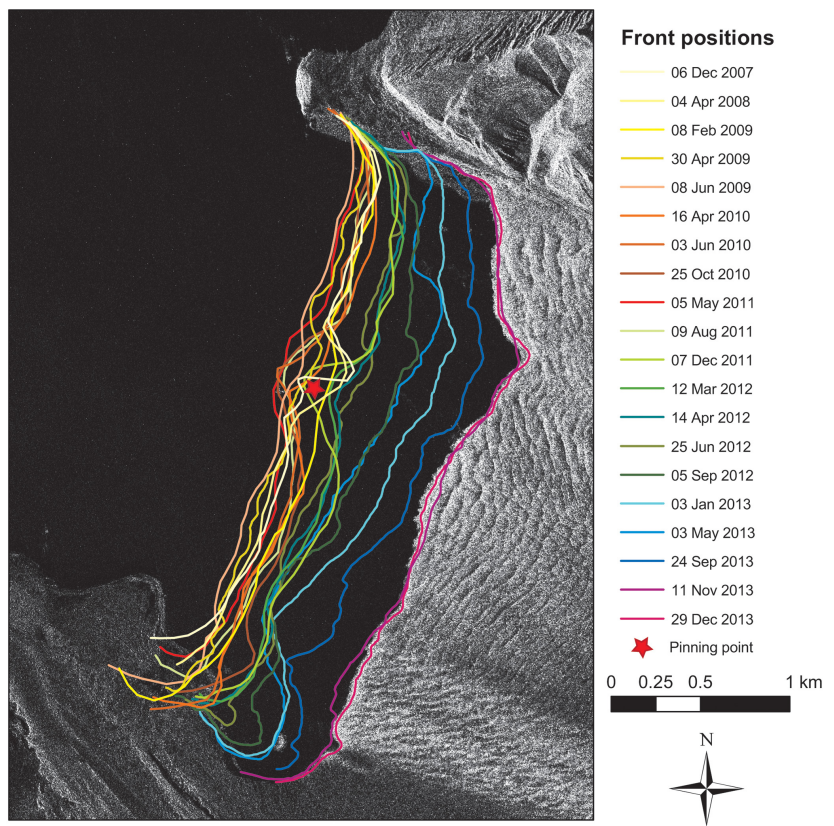

Figure 7. Selected calving front positions of Kronebreen between December 2007 and December 2013. Background image RS-2 UF of 29 December 2013.

$\left(0.17-0.33 \mathrm{Gta}^{-1}\right)$ (for ranges see paragraph above) with $q_{\mathrm{fg}}=0.21 \mathrm{Gt} \mathrm{a}^{-1}$ and $q_{\mathrm{t}}=0.06 \mathrm{Gt} \mathrm{a}^{-1}$ (Table 5).

\subsection{Kongsbreen}

\subsubsection{Glacier surface speed}

The coverage of the velocity maps derived for Kongsbreen is not as complete as for Kronebreen, and continuous in situ GPS measurements are not available. Therefore we choose two points $\mathrm{P}_{\# 1}$ and $\mathrm{P}_{\# 2}$ on Kongsbreen, where speed could be extracted from most of the velocity maps (see Fig. 10). These data indicate a seasonal velocity pattern of Kongsbreen similar to the one of Kronebreen between 2010 and 2011, with relatively stable background velocities during autumn and winter interrupted by a summer speedup during the melt season (Fig. 10)

The lowest speed at point $\mathrm{P}_{\# 1}$ was measured in autumn $2011\left(v_{P \# 1}=0.45 \mathrm{~m} \mathrm{~d}^{-1}\right)$ and increased linearly from then on. No data are available at the time of the extreme rain event in January 2012, but speed was at a comparable or lower level at $\mathrm{P}_{\# 1}$ and $\mathrm{P}_{\# 2}$ before than after the event, indicating that it had only a minor or short-term impact on glacier flow. Interestingly, the distinct summer peak was missing in 2012. The glacier flow stabilized in autumn 2012, and the highest speed of that year was measured in November/December $\left(v_{P \# 1}=1.32 \mathrm{~m} \mathrm{~d}^{-1}\right)$ keeping that level until summer 2013. After a short and minor speedup in June 2013 $\left(v_{P \# 1}=1.39 \mathrm{~m} \mathrm{~d}^{-1}\right)$, the speed dropped to $0.82 \mathrm{~m} \mathrm{~d}^{-1}$ in August 2013, just to accelerate to the highest observed speed of $1.43 \mathrm{~m} \mathrm{~d}^{-1}$ in November 2013. The speedups at Kongsbreen did not reach as far upglacier as in the case of Kronebreen; for example speeds greater than $1 \mathrm{~m} \mathrm{~d}^{-1}$ were measured up to $3.5 \mathrm{~km}$ inland from the calving front (Figs. 9 and 10). The evolution of the speed at $\mathrm{P}_{\# 2}$ follows a similar pattern, al- 


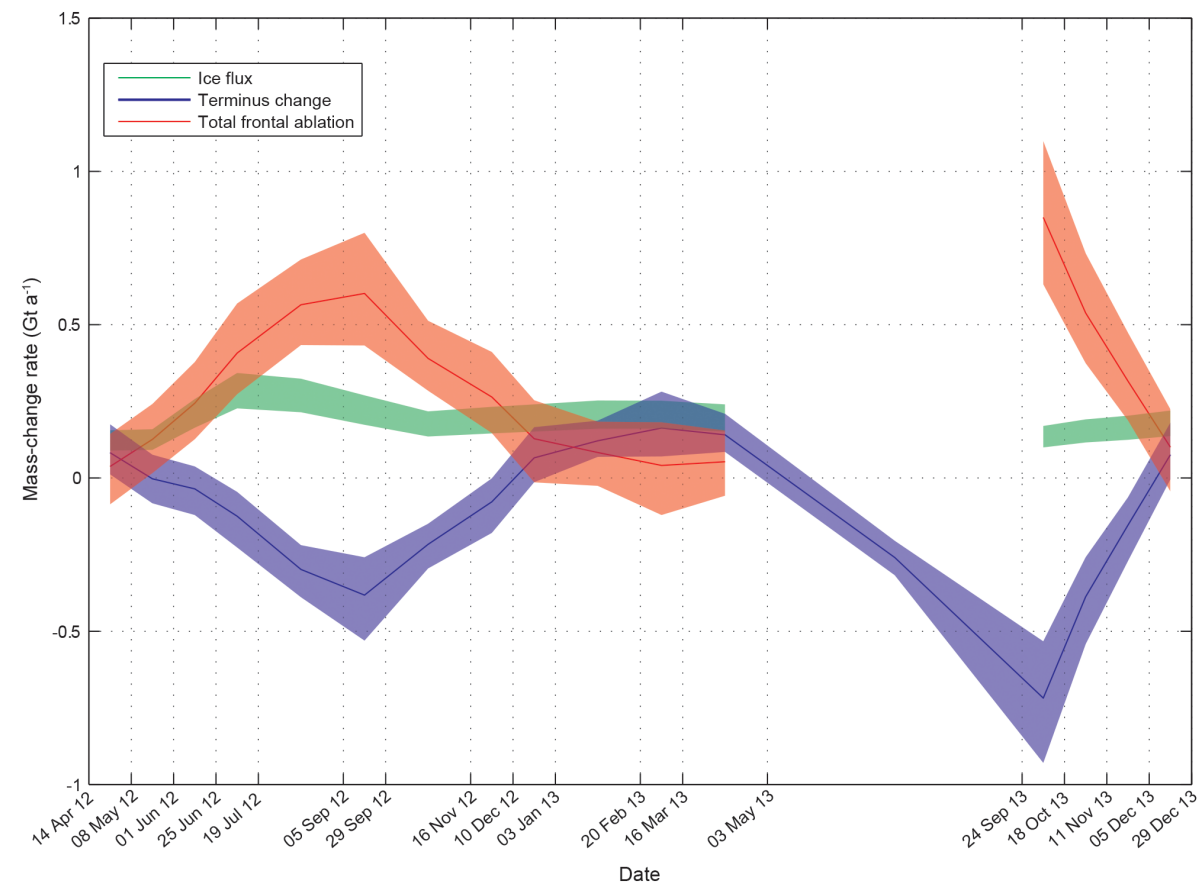

Figure 8. Frontal ablation of Kronebreen between 14 April 2012 and 29 December 2013 and components, ice flux and terminus position changes. Note that the ice flux could not be estimated between May and September 2013 as the quality of the speed map was not sufficient to extract glacier speed along the fluxgate.

Table 5. Total frontal ablation of Kronebreen and Kongsbreen and its components, ice flux and terminus position changes, in Gt $\mathrm{a}^{-1}$ during $\mathrm{P}_{1}$ (14 April 2012-29 December 2013, excluding 3 May 2013-24 September 2013) and $\mathrm{P}_{2}$ (8 May 2012-3 May 2013). Speed based on a depth-averaged velocity $\mathrm{f}_{\mathrm{da}}=0.8$ is considered as conservative estimate. Upper and lower boundaries based on error analysis are given in brackets.

\begin{tabular}{|c|c|c|c|c|c|}
\hline Glacier & Period & $f_{\mathrm{da}}$ & Ice flux $\left(\mathrm{Gt} \mathrm{a}^{-1}\right)$ & $\Delta$ Terminus $\left(\mathrm{Gt} \mathrm{a}^{-1}\right)$ & Frontal ablation $\left(\mathrm{Gt} \mathrm{a}^{-1}\right)$ \\
\hline \multirow{4}{*}{ Kronebreen } & \multirow{2}{*}{1} & 0.8 & $0.153(0.118 / 0.194)$ & -0.059 & $0.212(0.163 / 0.268)$ \\
\hline & & 1.0 & $0.192(0.150 / 0.238)$ & $(-0.074 /-0.045)$ & $0.250(0.195 / 0.312)$ \\
\hline & \multirow{2}{*}{2} & 0.8 & $0.165(0.128 / 0.207)$ & -0.059 & $0.224(0.173 / 0.282)$ \\
\hline & & 1.0 & $0.206(0.163 / 0.255)$ & $(-0.074 /-0.045)$ & $0.266(0.208 / 0.329)$ \\
\hline \multirow{4}{*}{ Kongsbreen } & \multirow{2}{*}{1} & 0.8 & $0.089(0.069 / 0.112)$ & -0.050 & $0.140(0.109 / 0.174)$ \\
\hline & & 1.0 & $0.122(0.088 / 0.138)$ & $(-0.062 /-0.040)$ & $0.162(0.128 / 0.200)$ \\
\hline & \multirow{2}{*}{2} & 0.8 & $0.088(0.68 / 0.111)$ & -0.061 & $0.149(0.117 / 0.185)$ \\
\hline & & 1.0 & $0.110(0.087 / 0.136)$ & $(-0.074 /-0.049)$ & $0.171(0.136 / 0.210)$ \\
\hline
\end{tabular}

though the distinct summer peaks did not develop as $\mathrm{P}_{\# 2}$ is located $\sim 7 \mathrm{~km}$ upglacier from the calving front at an elevation of $319 \mathrm{~m}$.

\subsubsection{Terminus position changes}

Between December 2007 and December 2013, the terminus of Kongsbreen retreated up to $1.8 \mathrm{~km}$, equivalent to an area loss of $2.5 \mathrm{~km}^{2}$. As for Kronebreen, the calving front position of Kongsbreen generally followed a seasonal cycle, characterized by an advance in spring, a retreat in autumn and minor fluctuations during winter and summer.
SAR images acquired in 2007 and 2008 do not indicate major changes in front position (Fig. 11). However, after autumn 2008, the glacier started to retreat. Between February and June 2009 Kongsbreen re-advanced by $\sim 200 \mathrm{~m}$ but did not reach its 2007/2008 position. There is a data gap until April 2010, but the abovementioned typical spring advance until June 2010 was captured. Kongsbreen reached a similar position as in 2009; only the southern part did not advance as much as the rest. The same sequence of front position changes repeated in 2011, with an advance until May 2011 towards the 2009 summer position, which was kept until 


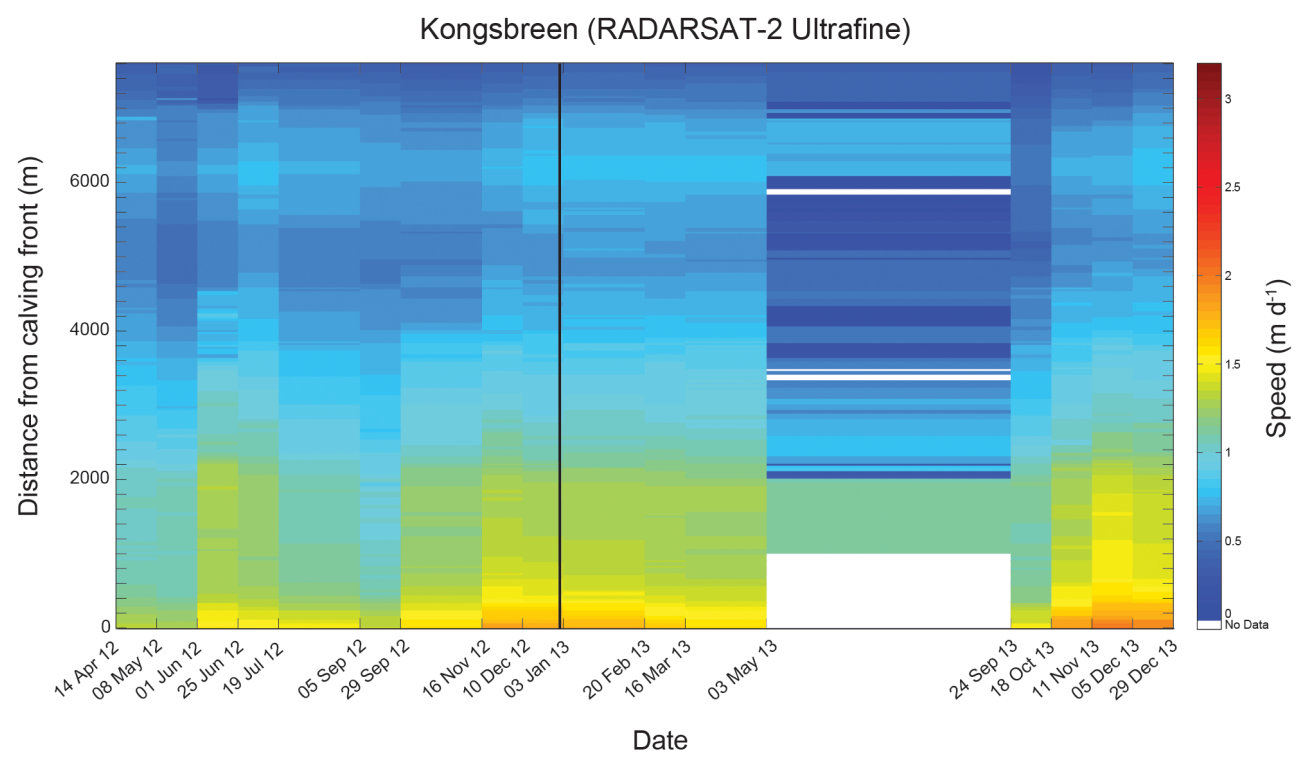

Figure 9. Time series of speed along centerline of Kongsbreen (Fig. 1) between 14 April 2012 and 29 December 2013 based on RS-2 UF data. Note the reduced quality of matching results and missing matches at the calving front between 3 May 2013 and 24 September 2013 due to the long time interval between acquisitions.

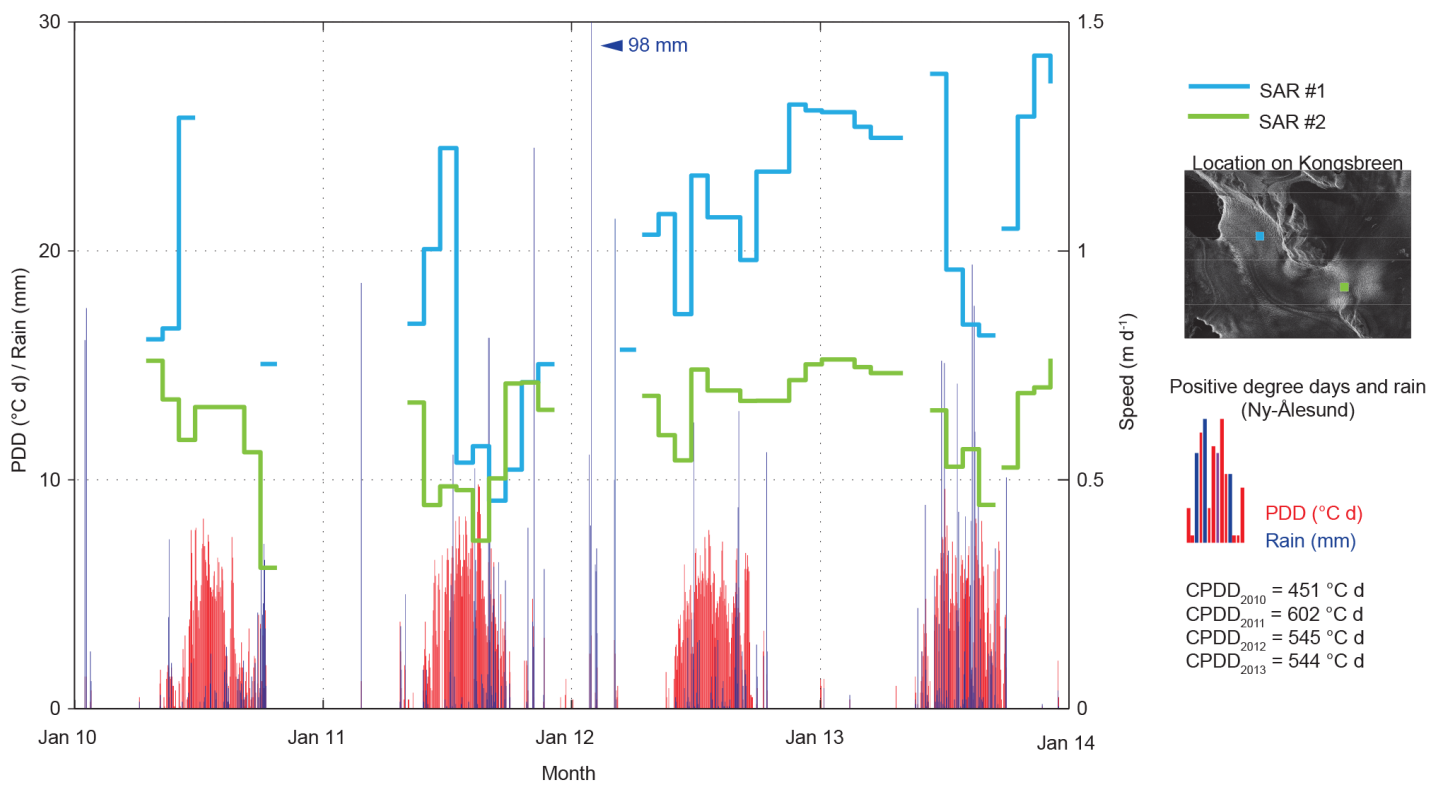

Figure 10. Time series of speed of Kongsbreen between 2010 and 2013 linked to water supply to the bed by melt and rain (positive degree days $\left({ }^{\circ} \mathrm{C}\right)$ and rain events (mm) from weather station in Ny-Ålesund). Speed at two points of Kongsbreen (m d $\left.{ }^{-1}\right)$ from RS-2 UF and RS-2 W (see inset).

July 2011. Kongsbreen then started to retreat, with a significant portion of the retreat $(\sim 500 \mathrm{~m})$ occurring between August 2011 and December 2011. We detected a minor advance until March 2012 but similar to Kronebreen no major advance occurred during spring. Between July 2012 and November 2012 the autumn recession happened, especially of the southern part. After relatively stable front position un- til December 2012, Kongsbreen advanced up to $350 \mathrm{~m}$ during spring and summer 2013. The yearly retreat started after July 2013 in the northern part and accelerated in the southern part after August 2013. 


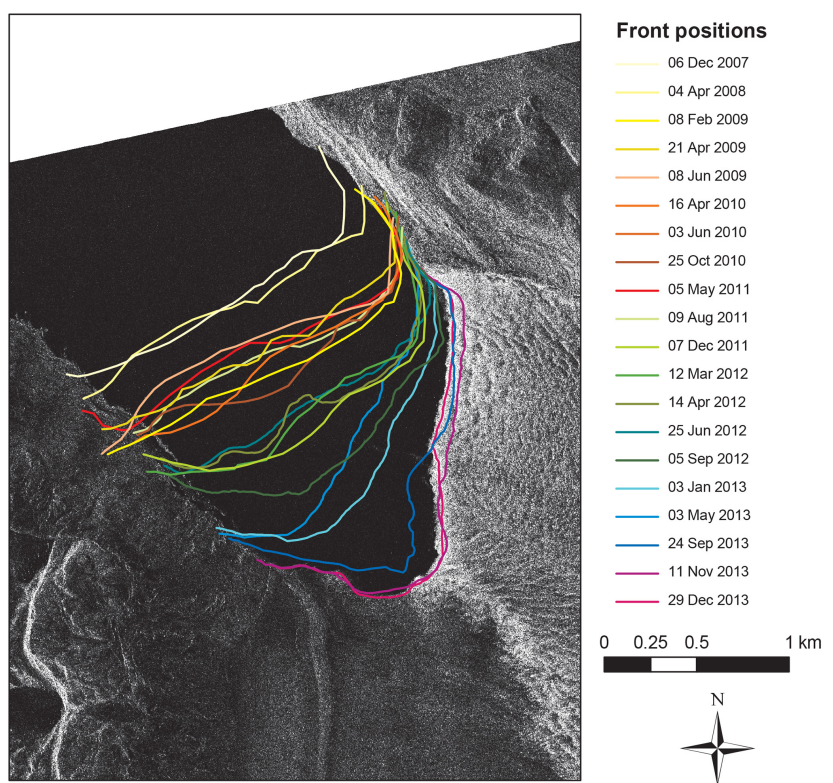

Figure 11. Selected calving front positions of Kongsbreen between December 2007 and December 2013. Background image RS-2 UF of 29 December 2013.

\subsubsection{Frontal ablation}

Mean frontal ablation rates of Kongsbreen between 14 April 2012 and 29 December 2013 by excluding the flux between 3 May and 24 September 2013 amounted to $q=0.14$ $0.16 \mathrm{Gta}^{-1}\left(0.11-0.20 \mathrm{Gta}^{-1}\right)$ (first range refers to different depth-averaged speed, second range to the complete error budget; see Sect. 4.2.2), whereof $0.05 \mathrm{Gta}^{-1}$ was lost through terminus position changes and $0.11 \mathrm{Gt} \mathrm{a}^{-1}$ through ice flux (Table 5). Between May 2012 and May 2013, frontal ablation was $q=0.15-0.17 \mathrm{Gt} \mathrm{a}^{-1}\left(0.12-0.21 \mathrm{Gta}^{-1}\right.$ ) (for ranges see previous sentence) with $q_{\mathrm{fg}}=0.11 \mathrm{Gta}^{-1}$ and $q_{\mathrm{t}}=0.06 \mathrm{Gt} \mathrm{a}^{-1}$. The temporal evolution of the frontal ablation is given by the frontal ablation between each RS-2 UF acquisition in Fig. 12.

Please note that the assumed cross-sectional fluxgate area and thus the computed ice flux represent a minimum estimate. We chose a location of the fluxgate (Fig. 1) that allows for extraction of values from all velocity maps. As Kongsbreen has retreated significantly ( $\sim$ several hundred meters) since the first acquisition in April 2012, the fluxgate was not located close to the calving front at the time of most of the acquisitions but up to several hundred meters upglacier, where the actual ice thickness is larger and speed is lower than close to the terminus. Upper and lower boundary of $q$ should in the case of Kongsbreen not be interpreted directly as formal accuracy but as the likely range based on the large uncertainties in the constraint of the fluxgate geometry.

\section{Discussion}

We described the interannual and seasonal variability in speed, calving front positions and frontal ablation of Kronebreen and Kongsbreen and confirm the high interannual variability in speed of Kronebreen found, e.g., by Kääb et al. (2005).

Over most of the observation period, the variability in glacier speed of both glaciers seems to be correlated with variations in amount and timing of surface meltwater input and rainfall. We attribute the observed correlation to the influence of meltwater and rainfall on the water pressure at the bed and basal lubrication according to the theory of Iken and Bindschadler (1986). We suggest that yearly speedups in summer are linked to increased availability of water in an inefficient drainage system at the glacier bed at the start of the melt season, which leads to enhanced basal lubrication. The water then successively creates a channelized system through which it can be drained efficiently, followed by a slowdown of the glacier to its autumn and winter background speed. Background speed is the almost constant minimum speed in autumn and winter. After the effective channelized system has evolved the speed drops as there is a lack of lubricant. When there is no longer enough water supply to sustain the channelized system at the end of the melt season, an inefficient system evolves which also lacks of lubricant, unless it is not raining (see secondary speed peaks).

This behavior has been observed at many glaciers in different regions in the world, e.g., the Alps (Iken and Bindschadler, 1986), Svalbard (Dunse et al., 2012), Canada (Copland et al., 2003) and Alaska (Burgess et al., 2013). In each year, secondary speed peaks were detected after the main melt induced summer speedup which are caused by rain events; the subglacial system is saturated for a short period again, allowing enhanced basal sliding.

The summer 2011 with the highest melt production $\left(\mathrm{CPDD}_{2011}=602^{\circ} \mathrm{Cd}\right)$ is particularly interesting, as the maximum speed at the calving front of Kronebreen stayed below the level of 2010 when summer was cooler $\left(\mathrm{CPDD}_{2010}=451^{\circ} \mathrm{Cd}\right)$. In 2011 the channelized system must have evolved faster, and the water was transported away from the bed more efficiently, hence leading to an early slowdown in the melt season. This behavior has previously been explained by Schoof (2010).

The flow of Kongsbreen was modulated from this typical pattern in 2012 and 2013, when the speed did not peak distinctively in summer but reached its maximum in late autumn. We speculate that an inefficient drainage system was maintained throughout. The water from the rain event was not evacuated and high water pressure maintained throughout the winter and spring. As winter velocities were already enhanced, the following summer speedup is less pronounced than in other years.

The increase in speed, which started already in autumn 2011, coincides with the onset of the retreat and hence re- 


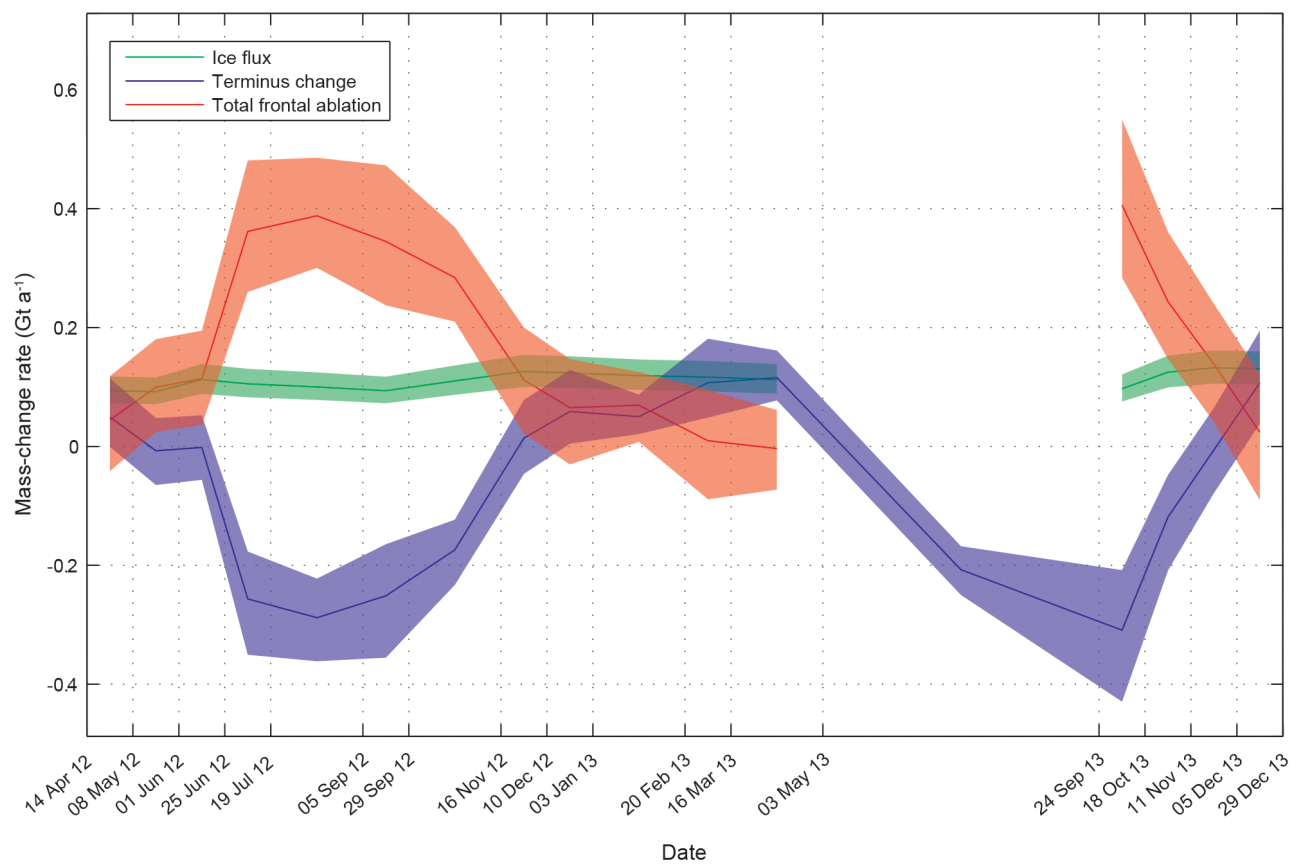

Figure 12. Frontal ablation of Kongsbreen between 14 April 2012 and 29 December 2013 and components, ice flux and terminus position changes. Note that the ice flux could not be estimated between May and September 2013 as the quality of the speed map was not sufficient to extract glacier speed along the fluxgate.

duced the back stress. Kongsbreen had already retreated by $1.0-1.7 \mathrm{~km}$ between 1990 and 2000 (Nuth et al., 2013) but has been relatively stable since then.

In general glacier advance occurs when the glacier flows at a higher rate than frontal ablation occurs, and a glacier retreats when frontal ablation rates exceeds the glacier flow. Advances regularly occur in spring and summer when the velocity is especially high due to enhanced lubrication and calving rates are low (Köhler et al., 2012). The timely occurrence of the retreat in autumn is in line with observations from Köhler et al. (2012), who found that in 2009 and 2010 calving-related seismicity at Kronebreen predominantly occurred in autumn, after the peak in velocity. In late summer and autumn decreased velocity and warm ocean water entering the fjord, hence increased melt, undercutting and calving, lead to retreat (Luckman et al., 2015).

We want to highlight here that the RS-2 data cover the start of the retreat of Kronebreen in autumn 2011 after a prolonged period of stable front positions since the 1990s (Nuth et al., 2012). One reasonable explanation is the detachment of Kronebreen from its long-term pinning point and retreat in a deeper section of the fjord. Warm water entering the fjord in autumn 2011 might have triggered the instability by intensifying melt and stronger undercutting at the calving front, which subsequently raised the calving rate as observed by Luckman et al. (2015) in 2013. The influence of the warm water might also have played an important role in spring 2012, when, in contrast to previous years and although the velocity was highest, no advance occurred, and frontal ablation must have occurred at the same rate as the glacier moved. Sea ice or ice mélange usually does not occur close to the calving front of Kronebreen and Kongsbreen, and hence it does not have an influence on the back pressure and glacier speed.

The SAR-based ice flux of the period May 2012 to May 2013 of $0.21 \mathrm{Gt} \mathrm{a}^{-1}\left(0.128-0.255 \mathrm{Gta}^{-1}\right)$ (range refers to the complete error budget; see Sect. 4.2.2) is in line with the estimate of the long-term ice flux of Kronebreen between 1990 and 2007 of $0.198 \pm 0.045 \mathrm{Gt} \mathrm{a}^{-1}$, derived from DEM differencing and mass balance modeling (Nuth et al., 2012). The importance of mass loss at the terminus is highlighted by the comparison to the surface mass balance of $-0.069 \pm 0.029$ (Nuth et al., 2012). The overall ice flux to the ocean from all 163 Svalbard glaciers was estimated to be $6.75 \pm 1.7 \mathrm{Gta}^{-1}$ (Blaszczyk et al., 2009), and Kronebreen and Kongsbreen are major contributors with shares of 4.0 and $2.5 \%$, respectively. Nevertheless, this number does not include mass loss related to major surges, such as of Basin3 on Austfonna since $2012\left(4.2 \pm 1.6 \mathrm{Gt} \mathrm{a}^{-1}\right.$, Dunse et al., 2015) and between 2009 and 2013 of Nathorstbreen (Sund et al., 2014).

The results of this study are largely based on speed maps derived from SAR feature tracking using RS-2 UF, RS-2 W and TSX data, whose quality mainly depends on high SAR image resolution and persistent surface conditions. Speed maps based on RS-2 UF data acquired in spring revealed 
good matching results (Fig. 2a) even within the slow-moving upper regions of the glaciers. In the summer data the number of well-matched displacements decreased in these areas (Fig. 2b) because of extensive melt changing the surface characteristics and destroying the visual coherence of the SAR intensity between the two acquisitions. Notably, the algorithm was able to achieve reasonable glacier speed estimates along the centreline of Kronebreen (Fig. 5a) and partially also Kongsbreen (Fig. 9) over a period of 144 days or 6 RS-2 repetition cycles (3 May and 24 September 2013). The lowest quality comes from the medium-resolution RS$2 \mathrm{~W}$ data, with a resolution of $100 \mathrm{~m}$ for the velocity maps (compared to $50 \mathrm{~m}$ for RS-2 UF) and frequent occurrence of mismatches resulting in gaps in the velocity maps, especially for the narrow Kongsbreen (Fig. 2c).

TSX, with a similar geometric resolution as RS-2 UF, provides less smooth speed fields and good matches are not achieved from as far upglacier as with RS-2 UF (Fig. 2d). This might be related to the different frequency, although a direct comparison is not possible here as the TSX and RS2 UF acquisitions do not overlap temporally. Usually, X-band coherence is considered less stable over time than C-band, due to its lower penetration depth. This is partially compensated by the shorter revisit time of TSX of 11 days, which then again is another possible reason for the absence of speed estimates in the slow-moving upper parts of the glaciers, as offset tracking has limited capability to resolve particularly small displacements. Interferometry fails completely for all SAR data available over glaciers due to loss of phase coherence.

\section{Conclusions}

For the first time, the speed patterns of Kronebreen and Kongsbreen were studied over the period of multiple years at a high temporal and spatial resolution. We used high- and medium-resolution SAR data from RS-1, RS-2 and TSX between 2007 and 2013 to extract glacier speed of Kronebreen and Kongsbreen in NW Svalbard. Especially the RS-2 UF and TSX data at high resolution provided area-wide displacement estimates with very high accuracy compared to GPS data from different stations on Kronebreen and stable ground. Due to the coarser resolution of the RS-1/RS-2 W data, the displacements are less accurate, especially for Kongsbreen and at the border between Kronebreen and the slow-moving Kongsvegen.

Both glaciers studied are among the fastest glaciers in Svalbard with maximal speeds close to the calving front of $3.2 \mathrm{~m} \mathrm{~d}^{-1}$ at Kronebreen in July 2013 and $2.7 \mathrm{md}^{-1}$ at Kongsbreen in December 2012. Part of the ice-flow variations is closely linked to the amount and timing of surface meltwater production and rainfall, both of which have a strong influence on the basal water pressure and lubrication. Since 2007 both glaciers also retreated significantly,
Kronebreen by $2.1 \mathrm{~km}^{2}$ and Kongsbreen by $2.4 \mathrm{~km}^{2}$, with the major part occurring after autumn 2011. The retreat and reduction in back stress is a possible explanation for high background velocities of Kronebreen and Kongsbreen in 2012 and 2013. The mean frontal ablation rate of Kronebreen between May 2012 and May 2013 was estimated from RS-2 UF data to $0.22-0.27 \mathrm{Gt} \mathrm{a}^{-1}\left(0.17-0.33 \mathrm{Gt} \mathrm{a}^{-1}\right)$ (first range refers the depth-averaged speed, second range in brackets to the complete error budget; see Sect. 4.2.2), divided into ice flux of $0.21 \mathrm{Gta}^{-1}$ and mass loss related to terminus position changes of $-0.06 \mathrm{Gta}^{-1}$. In the same period Kongsbreen lost $0.15-0.17 \mathrm{Gt} \mathrm{a}^{-1}\left(0.12-0.21 \mathrm{Gt} \mathrm{a}^{-1}\right)$ whereof $0.11 \mathrm{Gta}^{-1}$ came from the flux through the fluxgate and additionally $-0.06 \mathrm{Gta}^{-1}$ from terminus retreat. This makes both glaciers major contributors to the overall mass loss of the Svalbard archipelago through frontal ablation with shares of 4.0 and $2.5 \%$, respectively.

Author contributions. T. Schellenberger and A. Kääb designed the study. T. Schellenberger processed the data and wrote the manuscript. A. Kääb provided the RADARSAT and TerraSAR-X data. T. Dunse assisted in calculating the calving flux. J. Kohler provided the GPS data and the bedrock map of Kronebreen. C. H. Reijmer provided the GPS data. All coauthors contributed to or commented on the manuscript.

Acknowledgements. T. Schellenberger thanks T. V. Schuler and C. Nuth for discussions about the manuscript. This study was supported by the Research Council of Norway through RASTAR, grant number 208013, CRYOMET, grant number 214465. Fieldwork was supported by funding from the Svalbard Science Forum (NFR, RisID 6183). This publication is contribution number 57 of the Nordic Centre of Excellence SVALI, "Stability and Variations of Arctic Land Ice", funded by the Nordic Top-level Research Initiative (TRI). A. Kääb has received funding from the European Research Council under the European Union's Seventh Framework Programme (FP/2007-2013)/ERC grant agreement no. 320816, and the ESA project Glaciers_cci (4000109873/14/I-NB).

RADARSAT data were provided by NSC/KSAT under the Norwegian-Canadian Radarsat agreements 2007-2013. TerraSAR-X data are courtesy of DLR under proposal LAN_0211. Meteorological data were provided by the Norwegian Meteorological Institute, the Kongsfjord bathymetry by Statens Kartverk and Landsat 8 OLI data by USGS. The GPSs from the Institute for Marine and Atmospheric research, Utrecht (IMAU), Utrecht University, were funded by the Netherlands Polar Program (NPP) and the Netherlands Organization of Scientific Research, Earth and Life Sciences section (NWO/ALW).

Edited by: S. M. Noe 


\section{References}

Benn, D. I., Warren, C. R., and Mottram, R. H.: Calving processes and the dynamics of calving glaciers, Earth-Sci. Rev., 82, 143179, doi:10.1016/j.earscirev.2007.02.002, 2007.

Blaszczyk, M., Jania, J. A., and Hagen, J. O.: Tidewater glaciers of Svalbard: Recent changes and estimates of calving fluxes, Pol. Polar Res., 30, 85-142, 2009.

Burgess, E. W., Larsen, C. F., and Forster, R. R.: Summer melt regulates winter glacier flow speeds throughout Alaska, Geophys. Res. Lett., 40, 6160-6164, doi:10.1002/2013g1058228, 2013.

Church, J. A., Clark, P. U., Cazenave, A., Gregory, J. M., Jevrejeva, S., Levermann, A., Merrifield, M. A., Milne, G. A., Nerem, R. S., Nunn, P. D., Payne, A. J., Pfeffer, W. T., Stammer, D., and Unnikrishnan, A. S.: Sea Level Change, Cambridge University Press, Cambridge, UK and New York, NY, USA, 2013.

Clarke, G. K. C.: Fast glacier flow: Ice streams, surging, and tidewater glaciers, J. Geophys. Res., 92, 8835, doi:10.1029/JB092iB09p08835, 1987.

Cogley, J. G., Hock, R., Rasmussen, L. A., Arendt, A. A., Bauder, A., Braithwaite, R. J., Jansson, P., Kaser, G., Möller , M., Nicholson, L., and Zemp, M.: Glossary of Glacier Mass Balance and Related Terms, UNESCO-IHP, Paris, France, 2011.

Copland, L., Sharp, M. J., and Nienow, P. W.: Links between shortterm velocity variations and the subglacial hydrology of a predominantly cold polythermal glacier, J. Glaciol., 49, 337-348, 2003.

Cuffey, K. M. and Paterson, W. S. B.: The Physics of Glaciers, 4 ed., Academic Press, Oxford, UK, 704 pp., 2010.

den Ouden, M. A. G., Reijmer, C. H., Pohjola, V., van de Wal, R. S. W., Oerlemans, J., and Boot, W.: Stand-alone single-frequency GPS ice velocity observations on Nordenskiöldbreen, Svalbard, The Cryosphere, 4, 593-604, doi:10.5194/tc-4-593-2010, 2010.

Dunse, T., Schuler, T. V., Hagen, J. O., and Reijmer, C. H.: Seasonal speed-up of two outlet glaciers of Austfonna, Svalbard, inferred from continuous GPS measurements, The Cryosphere, 6, 453466, doi:10.5194/tc-6-453-2012, 2012.

Dunse, T., Schellenberger, T., Hagen, J. O., Kääb, A., Schuler, T. V., and Reijmer, C. H.: Glacier-surge mechanisms promoted by a hydro-thermodynamic feedback to summer melt, The Cryosphere, 9, 197-215, doi:10.5194/tc-9-197-2015, 2015.

Eldhuset, K., Andersen, P. H., Hauge, S., Isaksson, E., and Weydahl, D. J.: ERS tandem InSAR processing for DEM generation, glacier motion estimation and coherence analysis on Svalbard, Int. J. Remote Sens., 24, 1415-1437, doi:10.1080/01431160210153039, 2003.

Førland, E. J., Benestad, R., Hanssen-Bauer, I., Haugen, J. E., and Skaugen, T. E.: Temperature and Precipitation Development at Svalbard 1900-2100, Advances in Meteorology, 2011, 893790, doi:10.1155/2011/893790, 2011.

Hagen, J. O., Liestø1, O., Roland, E., and Jørgensen, T.: Glacier atlas of Svalbard and Jan Mayen, Norsk Polarinstitutt, Oslo, Norway, 1993.

Holland, D. M., Thomas, R. H., de Young, B., Ribergaard, M. H., and Lyberth, B.: Acceleration of Jakobshavn Isbræ triggered by warm subsurface ocean waters, Nat. Geosci., 1, 659-664, doi:10.1038/ngeo316, 2008.

Iken, A. and Bindschadler, R. A.: Combined measurements of subglacial water pressure and surface velocity of Findelengletscher,
Switzerland: Conclusions about drainage system and sliding mechanism, J. Glaciol., 32, 101-119, 1986.

Kääb, A., Lefauconnier, B., and Melvold, K.: Flow field of Kronebreen, Svalbard, using repeated Landsat 7 and ASTER data, Ann Glaciol, 42, 7-13, doi:10.3189/172756405781812916, 2005.

Köhler, A., Chapuis, A., Nuth, C., Kohler, J., and Weidle, C.: Autonomous detection of calving-related seismicity at Kronebreen, Svalbard, The Cryosphere, 6, 393-406, doi:10.5194/tc-6-3932012, 2012.

Korona, J., Berthier, E., Bernard, M., Rémy, F., and Thouvenot, E.: SPIRIT. SPOT 5 stereoscopic survey of Polar Ice: Reference Images and Topographies during the fourth International Polar Year (2007-2009), ISPRS Photogramm., 64, 204-212, doi:10.1016/j.isprsjprs.2008.10.005, 2009.

Lefauconnier, B.: Fluctuations glaciaires dans le Kongsfjord (Baie du roi): $79^{\circ}$ N. Spitsbergen, Svalbard: analyse et conséquences, $\mathrm{PhD}$, Institut de géographie alpine, Université scientifique, technologique et médicale de Grenoble, Grenoble, France, 252 pp., 1987.

Lefauconnier, B., Hagen, J. O., and Rudant, J. P.: Flow speed and calving rate of Kongsbreen glacier, Svalbard, using SPOT images, Polar Res., 13, 59-65, doi:10.3402/polar.v13i1.6681, 1994.

Liestøl, O.: The glaciers in the Kongsfjorden area, Spitsbergen, Norsk Geogr. Tidsskr. - Norwegian Journal of Geography, 42, 231-238, doi:10.1080/00291958808552205, 1988.

Luckman, A., Benn, D. I., Cottier, F., Bevan, S., Nilsen, F., and Inall, M.: Calving rates at tidewater glaciers vary strongly with ocean temperature, Nat. Commun., 6, 8566, doi:10.1038/ncomms9566, 2015.

Melvold, K.: Studie av brebevegelse på Kongsvegen og Kronebreen, Svalbard, Universitetet i Oslo, Oslo, Norway, 60, viii, 13 s., 62 fold. bl. ill. pp., 1992.

Melvold, K. and Hagen J, O.: Evolution of a surge-type glacier in its quiescent phase: Kongsvegen, Spitsbergen, 1964-95, J. Glaciol., 44, 394-404, 1998.

Motyka, R. J., Hunter, L., Echelmeyer, K. A., and Connor, C.: Submarine melting at the terminus of a temperate tidewater glacier, LeConte Glacier, Alaska, USA, Ann. Glaciol., 36, 5765, doi:10.3189/172756403781816374, 2003.

Nuth, C., Schuler, T. V., Kohler, J., Altena, B., and Hagen, J. O.: Estimating the long-term calving flux of Kronebreen, Svalbard, from geodetic elevation changes and mass-balance modelling, J. Glaciol., 58, 119-133, doi:10.3189/2012JoG11J036, 2012.

Nuth, C., Kohler, J., König, M., von Deschwanden, A., Hagen, J. O., Kääb, A., Moholdt, G., and Pettersson, R.: Decadal changes from a multi-temporal glacier inventory of Svalbard, The Cryosphere, 7, 1603-1621, doi:10.5194/tc-7-1603-2013, 2013.

Ohmura, A.: Physical Basis for the Temperature-Based Melt-Index Method, J. Appl. Meteorol., 40, 753-761, doi:10.1175/15200450(2001)040<0753:PBFTTB>2.0.CO;2, 2001.

Pillewizer, W. and Voigt, U.: Block movement of glaciers. Die wissenschaftlichen Ergebnisse der deutschen Spitzbergenexpedition 1964-1965, Geodätische und Geophysikalische Veröffentlichungen, 111, 1-138, 1968.

Pritchard, H. D., Ligtenberg, S. R. M., Fricker, H. A., Vaughan, D. G., van den Broeke, M. R., and Padman, L.: Antarctic ice-sheet loss driven by basal melting of ice shelves, Nature, 484, 502-505, doi:10.1038/Nature10968, 2012. 
Rolstad, C.: Satellitt- og flybilder til bestemmelse av bredynamikk (Satellite- and aerial photographs for determination of glacier dynamics), Master thesis, University of Oslo, Norway, 1995.

Rolstad, C. and Norland, R.: Ground-based interferometric radar for velocity and calving-rate measurements of the tidewater glacier at Kronebreen, Svalbard, Ann. Glaciol., 50, 47-54, doi:10.3189/172756409787769771, 2009.

Schoof, C.: Ice-sheet acceleration driven by melt supply variability, Nature, 468, 803-806, doi:10.1038/nature09618, 2010.

Strozzi, T., Luckman, A., Murray, T., Wegmuller, U., and Werner, C. L.: Glacier motion estimation using SAR offsettracking procedures, IEEE T. Geosci. Remote, 40, 2384-2391, doi:10.1109/TGRS.2002.805079, 2002.

Sund, M., Lauknes, T. R., and Eiken, T.: Surge dynamics in the Nathorstbreen glacier system, Svalbard, The Cryosphere, 8, 623638, doi:10.5194/tc-8-623-2014, 2014.
Svendsen, H., Beszczynska-Møller, A., Hagen, J. O., Lefauconnier, B., Tverberg, V., Gerland, S., Børre Ørbøk, J., Bischof, K., Papucci, C., Zajaczkowski, M., Azzolini, R., Bruland, O., and Wiencke, C.: The physical environment of KongsfjordenKrossfjorden, an Arctic fjord system in Svalbard, Polar Res., 21, 133-166, doi:10.3402/polar.v21i1.6479, 2002.

Vieli, A., Jania, J., and Kolondra, L.: The retreat of a tidewater glacier: observations and model calculations on Hansbreen, Spitsbergen, J. Glaciol., 48, 592-600, doi:10.3189/172756502781831089, 2002.

Wangensteen, B., Weydahl, D. J., and Hagen, J. O.: Mapping glacier velocities at Spitsbergen using ERS tandem SAR data, Geoscience and Remote Sensing Symposium, 1999, IGARSS'99 Proceedings, IEEE 1999 International, 28 June-2 July 1999, Hamburg, Germany, 1954-1956, 1999. 